\title{
REVISTAMARACANAN
}

Dossiê

\section{"A doçura que envolve": a culinária brasileira do Nordeste em Baú de Ossos}

\author{
"The sweetness that enthralls": Northeastern Brazilian cuisine in Baú de \\ Ossos
}

\author{
Maria Alice Ribeiro Gabriel* \\ Pesquisadora independente \\ Uberlândia, São Paulo, Brasil
}

Recebido em: 30 abr. 2020.

Aprovado em: 16 jul. 2020.

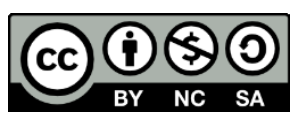

\footnotetext{
* Pesquisadora independente. Doutora em História Social pela Universidade de São Paulo; Mestre em Estudos Literários pela Universidade Estadual Paulista Júlio de Mesquita Filho; Graduada em Letras pela Universidade Federal de Uberlândia. E-mail: rgabriel1935@gmail.com

(iD) http://orcid.org/0000-0003-0256-1306 (9) http://lattes.cnpq.br/9257665714343943
} 


\title{
Resumo
}

A obra do médico e memorialista brasileiro Pedro da Silva Nava (1903-1984) oferece uma série de alusões à alimentação. Em Baú de Ossos (1972), primeiro volume das Memórias, inúmeras definições relativas à aparência, cores, sabores, componentes alimentares, ingredientes e texturas são apresentados e avaliados. Considerando o valor histórico de tais referências, este artigo pretende expor menções de Pedro Nava à cozinha regional, relativas à Região Nordeste, no século XIX e princípios do século XX. Este estudo desenvolve uma análise histórico-comparativa para examinar os temas relativos à alimentação e à culinária que emergem de episódios biográficos sobre a família Nava. A análise indica como Pedro Nava descreveu aspectos culturais e sociais de pratos populares e tradicionais do Nordeste brasileiro.

Palavras-chave: Pedro Nava. Memórias. História da Alimentação.

\begin{abstract}
The work of the Brazilian physician and memoirist Pedro da Silva Nava (1903-1984) offers a series of allusions to food. In Baú de Ossos (1972), first volume of his Memoirs, several definitions relating to appearance, colours, flavours, food components, ingredients and textures are presented and evalueted. Considering the historical value of these references, the aim of this article is to expose a number of Pedro Nava's mentions to regional culinary, regarding to the Northeast region of Brazil, in XIX century and early XX century. This study develops a comparative-historical analysis to examine the themes on food and culinary that emerged from biographical episodes about Nava's family. The analysis indicates how Pedro Nava depicted the cultural and social aspects of popular and traditional dishes from the Northeast of Brazil.
\end{abstract}

Keywords: Pedro Nava. Memoirs. Food History. 


\section{Considerações iniciais}

Tendo por fonte primária Baú de Ossos (1972), volume inaugural das Memórias do médico e escritor Pedro da Silva Nava (1903-1984), o objeto de estudo do presente artigo é a cozinha regional cearense do século XIX e da primeira década do século XX. ${ }^{1}$ Vários aspectos concernentes ao tópico da alimentação nos escritos do autor já foram discutidos por Raimundo Nunes, Lenina Lopes Soares Silva e Edina Regina Pugas Panichi, mas existe uma profusão de temas aguardando estudos nos escritos navianos, notadamente, sobre as inúmeras referências à culinária regional. Esta concerne, sobretudo, ao Ceará e Minas Gerais, estados natais das famílias paterna e materna do memorialista. ${ }^{2}$

Pedro Nava registrou panaceias: "Para refrescar o corpo, garapa de tamarindo. Para rebater o banho, pinga de macaxeira"; ${ }^{3}$ preferências alimentares e técnicas de preparação, como as da cozinha "da cearense D. Ana Cândida Pamplona da Silva Nava", avó paterna do autor: "Laboratório de onde saíam seus refrigerantes: cajuadas opalinas e adstringentes e seu leve aluá - não o de abacaxi, como em Minas, mas o da farinha de arroz ou de fubá fino, adoçado ao ponto e que, fermentado nos potes de barro, rebentava, na boca, em finas bolhas de quase vinho" e até utensílios que contribuem para a elaboração de uma imagem única da identidade da culinária regional na sociedade brasileira. ${ }^{4}$

Centrando-se em passagens nas quais Pedro Nava relata episódios biográficos de sua família paterna, "fixada nos costumes da boa burguesia do Norte. [...] Era assim na família cearense da Mundola Teixeira, na Pernambucana da Santa Freire, na baiana da Alzira Nilo", ${ }^{5}$ este estudo discute referências ao tema da alimentação em Baú de Ossos (1972), a fim de analisar como tais alusões, de início direcionadas aos hábitos de uma família da região Nordeste, revelam influências, ingredientes, técnicas de preparo, variações em cardápios tradicionais e adoção de novas práticas alimentares.

No campo dos Estudos Culturais, considerando as noções modernas de identidade, Robert Zussman divisou no texto (auto)biográfico narrativas socialmente estruturadas. As estruturas sociais que produzem narrativas (auto)biográficas manifestam-se em apontamentos de estudo e de trabalho, confissões de ordem religiosa ou criminal, escrita diarística, atas, terapias e organização de fotos em álbuns. Situações que estimulam as pessoas a relatar

\footnotetext{
${ }^{1}$ Adotando o mesmo princípio de alguns pesquisadores da obra de Pedro Nava, o termo Memórias foi grafado com inicial maiúscula ao designar os sete volumes de suas reminiscências: Baú de Ossos (1972), Balão Cativo (1973), Chão de Ferro (1976), Beira-Mar (1978), Galo das Trevas (1981), O Círio Perfeito (1983) e Cera das Almas (2006).

2 NUNES, Raimundo. Pedro Nava: Memória. São Paulo: Ateniense, 1987; SILVA, Lenina Lopes Soares. Narrativas do Brasil nas Memórias de Pedro Nava. 2010. Tese (Doutorado em Ciências Sociais) Universidade Federal do Rio Grande do Norte, Natal; PANICHI, Edina Regina Pugas. As genealogias culinárias de Pedro Nava. Manuscrítica: revista de crítica genética, São Paulo, n. 35, p. 65-77, 2018.

${ }^{3}$ NAVA, Pedro. Baú de Ossos. Rio de Janeiro: José Olympio, 1974, p. 23.

${ }^{4}$ Ibidem, p. 33.

${ }^{5}$ Ibidem, p. 32.
} 
eventos de suas vidas permitem que narrativa e estrutura social se encontrem. ${ }^{6}$ Para relatar e reconstituir o passado, Pedro Nava efetuou entrevistas e pesquisas, perscrutou genealogias e arquivos (o próprio e o de Antônio Salles), lançando mão de um conhecimento que afirmou ter cultivado do ponto de vista da "fuga para o convívio dos mortos".

É essencial recordar o passado, sob perspectiva ética, para honrar nosso débito com os mortos e tentar assegurar que certos erros não se repitam. A narrativa do passado recordado pode ajudar a representá-lo como ele realmente foi ou reinventá-lo, a partir do que poderia ter sido. Mas no caso do testemunho histórico, advertiu Richard Kearney, a evocação da verdade reclama a primazia. $^{8}$ Assim, este artigo fundamenta-se em estudos sobre a memorialística naviana e a história da alimentação.

\section{As "receitas de doce, receitas de droga, mezinhas" nos escritos de Pedro Nava}

Em Baú de Ossos, a cozinha do Nordeste é associada à biografia da família paterna do autor. O tema surge em passagens concernentes à vida do avô homônimo, Pedro da Silva Nava (1843-1880), "negociante e dono de casa comissária", nascido em São Luís do Maranhão e falecido no Rio de Janeiro, aos 37 anos. "O que se transmitiu até meu Pai e suas irmãs é que sua origem era italiana e que vinha de um certo Francisco Nava, que teria aportado ao Brasil no fim do século XVIII ou princípio do XIX". ${ }^{9}$ Apesar da pesquisa genealógica que realizou sobre o avô paterno, Pedro Nava "não podia subir senão duas gerações, parando no emigrante Francisco. [...] Em Bolonha estive no armazém de um Nava que vendia todas as variedades de pasta asciuta", referiu o memorialista, ao contar o que, "passando pela Itália, em 1955", apurou sobre a origem, possivelmente milanesa, do primeiro Nava "que deitou vergônteas no Maranhão (como as datas fazem acreditar)". ${ }^{10}$ À família se vincula a ideia de aprendizado e continuidade da tradição cultural, favorável à identidade do grupo.

Para José Maria Cançado, a relação entre as noções de identidade e tradição cultural mostra-se no intento, manifesto de forma expressa e recorrente nas Memórias, de preservar do esquecimento "os lugares, as cidades, o imaginário da história e das civilizações [...] um fabuloso fabulismo cultural [...]. Este é, ainda, o sonho da totalidade, o de pertencer a um sistema e provisão de formas, ideias, imagens do mundo [...] 0 [sonho] de pertencer a uma

\footnotetext{
${ }^{6}$ ZUSSMAN, Robert. Autobiographical occasions: introduction to the special issue. Qualitative sociology, v. 23 , n. 1,2000 , p. 5 . Sobre os estudos que focalizam a questão da identidade social, cabe ressaltar a contribuição dos filósofos Paul Ricoeur e Richard Kearney. Cf.: RICOEUR, Paul. Parcours de la reconnaissance. Paris: Stock, 2004; KEARNEY, Richard. On Stories. London; New York: Routledge, 2002.

${ }^{7}$ NAVA, Pedro. Baú de Ossos... Op. cit., p. 162.

${ }^{8}$ KEARNEY, Richard. On Stories... Op. cit., p. 69.

9 NAVA, Pedro. Baú de Ossos... Op. cit., p. 19-20.

${ }^{10}$ Ibidem, p. 19-20. Grifos no original.
} 
tradição e a um território". ${ }^{11}$ A orientação abrangente do registro cultural atribui viés enciclopédico aos escritos navianos, aspecto presente no sistema arquivístico do autor, notou Panichi, em uníssono com Silva: "Nas Memórias, ele informa que durante toda a vida fez um trabalho de assimilação cultural, que vai dos hábitos alimentares às maneiras de enterrar os mortos, e esse se encontra registrado em sua produção literária e científica". ${ }^{12}$

A memória dos que envelhecem [...] é o elemento básico na construção da tradição familiar. [...] Costumes de avô, responsos de avó, receitas de comida, crenças, canções, superstições familiares duram e são passadas adiante nas palestras de depois do jantar; nas das tardes de calor, nas varandas que escurecem; nas dos dias de batizado, de casamento, de velório (Ah! as conversas vertiginosas e inimitáveis dos velórios esquentadas a café forte e vinho-do-porto enquanto os defuntos se regelam e começam a ser esquecidos....). ${ }^{13}$

Parte desses costumes encontra-se vinculada aos primórdios do exercício da medicina no país. Nos ensaios da coletânea Território de Epidauro (1947), o autor descreve "práticas médicas do povo", condutas e saberes sobre propriedades fitoterápicas de ingredientes da farmacopeia, primeiro, popular e depois, oficial, a exemplo da beladona, do estramônio e do meimendro: "Eram as plantas do bem-estar, as ervas 'consoladoras' que o povo ia buscar" com curandeiros e raizeiros. ${ }^{14}$ Quando transcreve preparações e "mezinhas" utilizadas por "mineiros dos primórdios do século XVIII", o memorialista refere ingredientes comuns à medicina popular da época e, provavelmente, à despensa dos colonos: abóbora, "cujas variedades principais são a 'abóbora-d'água', a 'abóbora-menina', a 'abóbora enxuta' e a 'moganga', entram também, largamente, nas mezinhas de nosso povo" azeite, cebola, limão, ervas aromáticas (alecrim, malva), "miolo depam", "Vinagre do Reino" e vinho. ${ }^{15}$

Em estudo dividido em dois ensaios, Pedro Nava discorreu sobre "um caderno contendo 44 receitas", documento manuscrito datado do fim do século XVIII e princípios do XIX. Constavam das dietas e "medicamentos empregados": "Purgas de velame, jalapa, aguardente 'da terra', pimenta da Índia, mel de abelhas, aroeira, açúcar, jatobá, breu, 'peles de cobra', limão-galego, unto de porco, fumo, olhos de pinhão, 'bosta de boi', pão (para fazer a 'sopa de cavalo cansada' - 23a Receita)". ${ }^{16}$

Do manuscrito constavam ainda "versos que permitem dizer que o dono do caderno devia morar em Minas, porque ao transcrevê-los assinalou no alto da página que eles eram da autoria de 'hum Estudante de Lisboa que veyo ahuãs Cobranças ou buscar huã Erança ás

${ }^{11}$ CANÇADO, José Maria. Memórias videntes do Brasil: a obra de Pedro Nava. Belo Horizonte: Ed. UFMG, 2003, p. 45-46.

12 PANICHI, Edina Regina Pugas. Processos de construção de formas na criação: o projeto poético de Pedro Nava. Londrina, PR: Eduel, 2016; SILVA, Lenina Lopes Soares. Narrativas do Brasil... Op. cit., p. 54.

${ }_{13}$ NAVA, Pedro. Baú de Ossos... Op. cit., p. 17.

${ }^{14}$ NAVA, Pedro. Território de Epidauro: Crônicas e Histórias da História da Medicina. São Paulo: Ateliê, 2003, p. 110. Capítulo "Entre Bruxos e Doutores".

${ }^{15}$ Ibidem, p. 159, 168. Capítulo "Estudo interpretativo de quatro receitas de medicina caseira datando do século XVIII".

${ }_{16}$ Ibidem, p. 220-221. Capítulo "Um Manuscrito de Medicina Popular do Fim do Século XVIII e Princípios do XIX. I". 
Minas Gerais desta America'"'. ${ }^{17} \mathrm{O}$ caderno é valioso documento para o estudo das práticas médicas no período colonial, mas também dos ingredientes da cozinha sertaneja, da qual participavam saberes de culturas diversas.

Josué de Castro, médico e geógrafo pernambucano, comentou a influência cultural africana, indígena e portuguesa na alimentação do sertanejo em diferentes regiões do Brasil, por exemplo, "através da introdução feliz de certas plantas africanas e do uso de certos processos culinários que se mostraram excelentes no aproveitamento dos recursos alimentares da região"; através dos produtos da mandioca e do milho, que os povos indígenas "fixaram no panorama da cozinha regional afora o preparo da pamonha, da canjica de milho, do beiju da farinha de mandioca e da paçoca"; já "a rebuscada cozinha do Nordeste açucareiro, sempre tão adocicada ou lambuzada de azeite, representa um traço de alta compreensão do colono português e do mameluco seu descendente, em face das contingências especiais do meio geográfico". ${ }^{18}$ Adaptando-se a essas "contingências", alguns pratos ficaram conhecidos em espaços distantes da região de origem, integrados a cozinhas de todo o país:

Canjica de milho verde tremendo como seio de moça e geleia de mocotó rebolando como bunda de negra. Mocotó batido, em espuma que se solidifica para comer frio. Pamonha na palha - para comer quente, queimando os dedos. Melado. Tudo isto variando de casa para casa, segundo os segredos de suas donas e as invenções de suas negras - se desdobrando em outros pratos, se multiplicando em novos. Dos aristocráticos, com receitas, pedindo logo de saída 36 gemas, aos populares, como o cuscuz (só fubá, só açúcar, só vapor d'água e tempo certo). ${ }^{19}$

Ao descrever pratos tradicionais da cozinha nacional, o médico e folclorista baiano Fernando José de São Paulo observa, de modo análogo a Pedro Nava e Josué de Castro, a questão da variação que ocorre no preparo, por exemplo, da pamonha: "Iguaria em que o milho verde toma parte principal. Tem variantes regionais, em conformidade com elementos auxiliares (coco, leite de vaca, manteiga, sal, açúcar...) a maneira de preparo, a forma definitiva". ${ }^{20}$ Para Gilberto Freyre, a história da doçaria nacional oferece uma visão geral dos hábitos alimentares da população, moldados ao longo do tempo por práticas interculturais que compreendem fatores econômicos, geográficos, linguísticos e sociais:

Não só, porém, são diferentes as predominâncias estéticas e, por vezes, mágicas, de formas: também as de sabores, de combinações do sabor do açúcar com outros sabores, de usos e de abusos do açúcar no preparo de doces e de bolos brasileiros nas várias regiões do país. [...] Há, assim, no Brasil, uma geografia do doce em que a excelência da arte de sobremesa nem sempre corresponde à intensidade regional na produção de açúcar. [...] Entre o açúcar e quanto produto do trópico foi se prestando a ser cozinhado em tachos até tornar-se doce ou quitute de uma nova espécie, alimento meio português, meio

\footnotetext{
${ }^{17}$ NAVA, Pedro. Território de Epidauro... Op. cit., p. 218. Capítulo "Um Manuscrito de Medicina Popular do Fim do Século XVIII e Princípios do XIX. I".

18 CASTRO, Josué. Geografia da fome. Rio de Janeiro: Casa do Estudante do Brasil, 1953, p. 100, 112, 183, respectivamente.

19 NAVA, Pedro. Baú de Ossos... Op. cit., p. 161.

${ }^{20}$ PAULO, Fernando José de São. Linguagem Médica Popular no Brasil. Vol. 2. Salvador: Itapuã, 1970.
} 
tropical, agradável ao paladar, além de nutritivo. Uniões a que foram sendo acrescentadas a canela do Oriente, o cravo, a noz-moscada. ${ }^{21}$

É difícil precisar com exatidão todas as influências culturais que deram forma e sabor a esses pratos, devido à escassez de fontes documentais sobre a alimentação no período colonial, à parte do registro de livros conventuais e da Literatura de viagem, faltam informações sobre a existência de escritos domésticos: ${ }^{22}$

\begin{abstract}
anotações, cadernos de receitas, diários ou jornais íntimos que descrevam [...] de modo específico, o doce, o bolo, o quindim feito com açúcar por aquelas mulheres que todos os dias faziam renda e, todas as semanas, faziam doce: umas nas suas casas-grandes ou nos seus sobrados; outras, nas suas casas de porta e janela e até nos seus simples mocambos. ${ }^{23}$
\end{abstract}

Tais fontes, nos termos de Pedro Nava, encerrariam "os segredos de suas donas e as invenções de suas negras". ${ }^{24}$

Mesmo o preparo de pratos convencionais na culinária nacional varia, no tempo e no espaço, podendo estar profundamente embebido em tradições, combinando práticas culturais de origem vária, tal como a herança religiosa de cada povo. A influência da religião abrange datas particulares ligadas a fatos marcantes, celebrações, restrições e ritos que deram origem a certos costumes, por exemplo, os diversos modos de fazer massas, como o pão ázimo da Páscoa judaica ou o hábito de traçar o sinal da cruz sobre a farinha antes de se preparar o alimento. O historiador da alimentação Silvano Serventi escreveu sobre tal hábito, considerando distinções e aproximações entre o Judaísmo e o Cristianismo. Na tradição enraizada na liturgia cristã, o pão consumido à mesa não era partido antes de ser abençoado com o sinal da cruz, que marcava a superfície dos pães levados ao forno. As preparações à base de grãos inteiros ou grosseiramente partidos eram consideradas profanas. A massa do pão teve nesse contexto estreita relação com o sagrado. ${ }^{25}$ Frei Pedro de Poyares, franciscano da Província de Piedade, pregador e lente de Teologia no Convento de São Francisco de Elvas, em documento datado de 1672, registrou o costume antigo, unido à legenda áurea, conforme o excerto transcrito a seguir:

Costume era na Província de Valeria, imprimir o sinal da cruz nos pães, que se haviam de cozer; em certa ocasião meteu-se o pão no forno sem ser marcado; o monge Martírio à porta do forno o benzeu, fazendo sobre o pão, que estava no forno o sinal da Cruz: coisa maravilhosa! Notável prodígio! O pão à vista do

\footnotetext{
21 FREYRE, Gilberto. Açúcar: Uma sociologia do doce, com receitas de bolos e doces do Nordeste do Brasil. São Paulo: Global, 2012, p. 25-27.

22 Sobre os livros conventuais, cf.: ALGRANTI, Leila Mezan. Doces de ovos, doces de freiras: a doçaria dos conventos portugueses no livro de receitas da Irmã Maria Leocádia do Monte do Carmo (1729). Cadernos Pagu, Campinas (SP), n. 17-18, p. 397-408, 2001-2002.

${ }^{23}$ FREYRE, Gilberto. Açúcar... Op. cit., p. 31.

${ }^{24}$ Idem.

25 SERVENTI, Silvano; SABBAN, Françoise. Pasta: The Story of a Universal Food. New York: Columbia University Press, 2002, p. 22.
} 
santo sinal, à vista de tanta bênção, estalou, como panela, que estoura, e saiu do forno selado com o selo da Santa Cruz. ${ }^{26}$

Recordando a "tradição fantástica das Procissões das Almas", conhecida na região da Galícia como La Santa Compaña e disseminada na Espanha, em Portugal e toda a Europa, Câmara Cascudo referiu uma versão de narrativa popular que concilia dois aspectos culturais relacionados ao pão, o primeiro distingue o caráter sagrado do alimento; o segundo, o que denominou "o vínculo obrigacional pela alimentação em comum". "Comer estabelece um vínculo obrigacional que outrora possuía significação sagrada [...] De comer junto o pão veio o 'companheiro': cum panis (com o pão) com a sinonímia francesa de compagnon, compaing, compain, copain, copin". ${ }^{27} \mathrm{O}$ imaginário cristão é evocado por imagens, tais como: a ideia de penitência, a encruzilhada, a cruz processional de madeira que "as almas não têm força física para suster e transportar" e o pão ofertado na jornada:

Noutras regiões galegas uma alma do outro mundo, uma visão, oferece pão nas encruzilhadas. Se o homem aceitar o pão e o comer, estará condenado ao fadário de carregar a cruz. [...] O essencial é não comer pão oferecido pelo fantasma, não servir-se do alimento maravilhoso. ${ }^{28}$

Na exegese do padre Antônio Vieira encontram-se inúmeras referências à simbologia do pão no Antigo e Novo Testamento. O "Sermão da Primeira Dominga da Quaresma", pregado na Igreja de Santo Antônio, entre 1669 e 1674, explora a metáfora do pão como alimento pertencente ao âmbito do sagrado, mas, igualmente, como princípio de cobiça e perdição, a partir da passagem da tentação de Cristo no deserto. A imagem do "pão oferecido pelo fantasma" comentada por Câmara Cascudo torna-se mais clara para o leitor hodierno quando assente na arguição e contexto do jesuíta barroco:

Na primeira tentação tentou o demônio a Cristo com pão: Dize que estas pedras se convertam em pães - na terceira tentou-o com tudo: Tudo isto te darei - e em ambas pode cair facilmente o tentado, ou por fome ou por cobiça. [...] Aos que nada têm tenta-os o diabo com o pão, aos que nada lhes basta tenta-os com tudo; e sendo tão perigosa tentação a da necessidade como a da cobiça [...] do lícito se passa ao ilícito, e do justo ao injusto, e do necessário ao supérfluo, e do supérfluo ao nocivo e mortal [...]. Por isso o demônio começou a primeira tentação pelo pão, e acabou a segunda pelo precipício. ${ }^{29}$

Cultura, nacionalidade e religião afetam diretamente os hábitos alimentares, compreendendo o conteúdo simbólico dos alimentos. Muitas vezes a religião predomina sobre questões territoriais e culturais, a exemplo dos judeus que observam as prescrições alimentares da lei judaica, independente do país em que estejam. Assim, é possível que certos pratos desenvolvidos fora da cultura e história específicos de uma região tenham sido

\footnotetext{
${ }^{26}$ POYARES, Pedro de. Tractado panegyrico em louvor da Villa de Barcellos por rezam do apparecimento de cruzes que nela aparecem. Coimbra: Officina de Joseph Ferre, 1672, p. 182.

${ }^{27}$ CASCUDO, Luís da Câmara. Superstição no Brasil. São Paulo: Global, 2002, p. 218. Capítulo "O vínculo obrigacional pela alimentação em comum".

${ }^{28}$ Ibidem, p. 42. Capítulo "Perséfone e os 7 bagos da romã".

${ }^{29}$ VIEIRA, António. Sermão da Primeira Dominga da Quaresma. In: Obras Completas do Padre António Vieira. Sermões. Vol. I. Porto: Lello \& Irmão, 1999, p. 837-846.
} 
integrados por emigrantes à dieta de outros povos. Ambiente, aspectos sensoriais, psicológicos e sociais também podem determinar o comportamento alimentar.

"No estudo da cozinha do sertanejo nordestino, a mais isenta de influência tanto índia como negra, quase que se podendo chamá-la de colonial pura ou de reinol", Castro referiu conhecimentos trazidos à colônia pelo emigrante da Península ibérica, sobretudo, o saber absorvido da presença árabe na Andaluzia para "explorar o potencial agrícola da Espanha meridional". ${ }^{30}$ Tal influência moldou o cultivo de jardins e pomares, o preparo de alimentos e o uso de temperos:

O cuscuz é um prato típico da cozinha sertaneja, cuja técnica de preparo constitui uma simples variante dos processos árabes de fabricação de seu prato nacional - o kous-kous. Apenas, em lugar do grão de trigo, usa-se o de milho pilado, no Nordeste como na Arábia, num pilão especial. ${ }^{31}$

Castro vislumbrou no "cearense, exemplar típico de nômade brasileiro", recursos de adaptação e sobrevivência do árabe de regiões áridas. ${ }^{32}$ Luis Soler fez uma comparação análoga "nos terrenos da culinária, dos licores e bebidas tradicionais":

Nesta perspectiva é que se tornaria fácil explicar muitas coincidências curiosas entre tradições muçulmanas e sertanejas, mesmo no homem do sertão que não prima pela racialidade árabe: o lenço cobrindo boca e pescoço das mulheres, a instituição da cabra na vida caseira, o amor ao cavalo - um verdadeiro culto, entre os sertanejos -, muitos tipos de comida: as coalhadas e os requeijões sertanejos, o cuscuz - o "alcuscuz" dos árabes -, etc. ${ }^{33}$

As expressões culinárias cosmopolitas brasileiras remontantes à Península Ibérica possuem a influência de tradições da cristandade católica-romana e do mundo árabemuçulmano. Se Luís Soler associou a presença de uma rica variedade de especiarias e aromas na cozinha sertaneja nordestina à culinária de origem árabe, Ana Judith de Carvalho explicou que outra variedade da cozinha sertaneja formou-se em condições geográficas particulares que minoraram determinadas influências culturais:

No interior nordestino encontramos a verdadeira comida sertaneja. A presença africana deixa de ser predominante, e a culinária, apesar das influências portuguesa e indígena, denota forte personalidade própria. O azeite-de-dendê praticamente desaparece, permanecendo porém o coco e a pimenta. A carne fresca, especialmente no sertão, é menos empregada. ${ }^{34}$

A culinária do Nordeste é produto do amálgama de influências culturais distintas, adquirindo, no período colonial, particularidades que provieram inicialmente das mãos de invasores, mercadores e missionários europeus, e do contato destes com o trabalho escravo africano e indígena. Porém, essa culinária se diferencia ao apresentar características regionais autênticas em alguns lugares do sertão:

${ }^{30}$ CASTRO, Josué. Geografia da fome... Op. cit., p. 150, 107.

${ }^{31}$ Ibidem, p. 176.

32 Ibidem, p. 184.

${ }^{33}$ SOLER, Luís. Origens árabes no folclore do sertão brasileiro. Florianópolis: Ed. UFSC, 1995, p. 76.

34 CARVALHO, Ana Judith de. Cozinha típica brasileira: sertaneja e regional. Rio de Janeiro: Ediouro, 1998 , p. 68. 
Coalhada com carne-de-sol, costela de carneiro com pirão de leite, paçoca com bananas, milho cozido, feijão verde, o mungunzá que o africano ensinou e a carne moqueada que ele aprendeu com o indígena [...]. O milho e o leite constituem bases alimentares de primeira ordem, e tendo a vantagem do sabor e da fácil aquisição. ${ }^{35}$

O cronista João Nogueira (1867-1947), referido por Pedro Nava em Baú de Ossos como "meu preclaro primo Joãzinho Nogueira - para o público o Dr. João Franklin de Alencar Nogueira, engenheiro e historiador eminente", ${ }^{36}$ escreveu que, no início do século XIX, durante a peregrinação dos caboclos do aldeamento de Arronches, levando uma corda de espinhos e um retábulo com a efígie do Bom Jesus, "costume tradicional e mais antigo do Ceará", o dia era considerado santo nos lugares onde eram recebidos os peregrinos. "Depois do Terço vinha a ceia em que, nos fins d'água, já tendo o campo reverdecido, o gado limpado o pelo e a abundância reinado por toda parte, comia-se leite e tomava-se grande quantidade de coalhada endurecida, a que chamavam coalhada de lapada". ${ }^{37}$

Para descrever o sobrado de seu padrinho Joaquim Feijó de Melo, segundo marido de D. Ana Cândida Pamplona da Silva Nava, Pedro Nava parte das recordações da viagem feita ao Ceará, em 1919, na companhia do tio Antônio Salles: "na casa fraternal e acolhedora. Vão chegando, entrando, abancando para o gamão [...] ou em torno à mesa de jantar onde já estava, para quem queria, o clássico leite endurecido usado na terra para repasto noturno - a ancestral coalhada de lapada". ${ }^{38}$

"A ceia, no inverno, era uma tigela de coalhada, que se lapeava com uma colher de ferro ou de latão". ${ }^{39}$ A coalhada "de lapada" seria um produto da cozinha sertaneja para ser consumido após o anoitecer. Na sociedade rural do Nordeste, segundo o escritor Manuel Rodrigues de Melo: "Às sete horas da noite [...] era a ceia constituída de coalhada com muita nata, rapadura e farinha. Depois da coalhada vinham as histórias de trancoso, as adivinhações, ora ao estalar das vagens secas de feijão, nas debulhas coletivas, ora ao rucoruco das espigas de milho". ${ }^{40} \mathrm{Em}$ regiões mais agrestes do sertão, a invernada ou época das chuvas corresponde a um período de abastecimento e fartura, favorável aos rebanhos, à formação temporária de cacimbas e pastagens para engorda do gado esmaecido pela seca. Fabricam-se mantimentos e o produto das colheitas de mandioca e milho é armazenado:

E não é só com milho que se consome leite em abundância no sertão do Nordeste, mas de muitas outras formas. Misturado com café de manhãzinha, ou como coalhada fresca ou escorrida, ou sob a forma de derivados, manteiga ou

${ }^{35}$ CASCUDO, Luís da Câmara. Viajando o Sertão. Natal: Fundação José Augusto; CERN, 1984, p. $27-29$. Capítulo "Em defesa da cozinha sertaneja".

36 NAVA, Pedro. Baú de Ossos... Op. cit., p. 28.

37 NOGUEIRA, João. Hábitos e costumes cearenses. In: GIRÂO, Raimundo. O Ceará. Fortaleza: Ed. Fortaleza, 1945, p. 70.

38 NAVA, Pedro. Baú de Ossos... Op. cit., p. 28.

39 BRÍGIDO, João. Outrora, no Ceará. In: CASCUDO, Luís da Câmara. Antologia da Alimentação no Brasil. São Paulo: Global, 2008, p. 165. Grifos no original.

40 MELO, Manoel Rodrigues de. Patriarcas e carreiros: influência do coronel e do carro de boi na sociedade rural do Nordeste. Natal: Ed. Universitária, 1985, p. 128. 
queijo. Principalmente manteiga fresca e requeijão, tipo de queijo gordo de que os sertanejos fazem largo uso, cru ou assado. ${ }^{41}$

Se existe um domínio na cultura popular marcado por improvisações originais, recomposições criativas, influências multiculturais, variedade de usos, costumes e preparações, este domínio é o da alimentação. Cumpre notar o alcance simbólico dos alimentos, capaz de se projetar no plano religioso, psíquico (envolvendo imaginação e memória) e socioeconômico. Igualmente rica é a versatilidade na apresentação dos pratos e, nestes, a conciliação de experiências sensoriais, tópicos que o memorialista explora constantemente. Ao definir o repertório de sabores da cozinha de D. Nanoca, expôs ao leitor os tipos de açúcar, usos, aromas e sabores: "Compor com o açúcar é como compor com a nota musical ou a cor, pois uma e outra variam e se desfiguram, configuram ou transfiguram segundo os outros sons e os outros tons que se lhes aproximam ou avizinham". ${ }^{42}$ A constância do tema da alimentação nas páginas biográficas sobre as famílias paterna e materna, sugere a extensão da pesquisa realizada para descrever a "alquimia fabulosa" "da copa e da cozinha" de ambientes públicos e privados.

\begin{abstract}
A história da cozinha brasileira - elementos indígenas, portugueses, africanos, o que nos veio da França, a presença do Oriente por intermédio de Portugal e da Espanha, molhos, condutos, aparelhagem doméstica, superstições relativas à alimentação, dietas, tabus, condimentos, alguns com intenção mágica [...] é assunto merecedor de inquéritos e sistemáticas para o quadro realístico de nossa Etnografia tradicional. ${ }^{43}$
\end{abstract}

Em uníssono com Câmara Cascudo, ele afirmou nos seus escritos sobre a história da medicina: "Muita conclusão cultural poderia nascer dessas investigações, úteis à sociologia, à antropologia, à antropogeografia e à psicologia profunda da coletividade". ${ }^{44}$ Nesse sentido, diz Silva, Pedro Nava: "descreve costumes, práticas e linguagens populares como aquelas ligadas às práticas de cura e à alimentação no Brasil. Sendo assim, as memórias são uma fonte de saberes eruditos e populares, narrativas brasileiras focadas na existência dos seres humanos em sociedade e na dos laços culturais". ${ }^{45}$

A valiosa compilação de receitas dos escritos de Pedro Nava relativos à história da medicina permite ao pesquisador inferir uma parte do percurso de composição desses textos, conforme o autor alude a fontes orais, documentais e bibliográficas de origens diversas, a exemplo das passagens a seguir: ${ }^{46}$

Rocha Pitta, na História da América Portuguesa, dá farta informação sobre os alimentos difundidos no seu tempo. Frutos estrangeiros já aqui aclimatados como os pêssegos, figos, pêras, marmelos, uvas, romãs, melancias e melões.

\footnotetext{
${ }^{41}$ CASTRO, Josué. Geografia da fome... Op. cit. , p. 184.

42 NAVA, Pedro. Baú de Ossos... Op. cit., p. 34.

43 CASCUDO, Luís da Câmara. Doces de tabuleiro. In: Antologia da Alimentação no Brasil. São Paulo: Global, 2008, p. 251.

${ }^{44}$ NAVA, Pedro. Território de Epidauro... Op. cit., p. 111. Capítulo "Entre Bruxos e Doutores".

45 SILVA, Lenina Lopes Soares. Narrativas do Brasil... Op. cit., p. 47.

46 NAVA, Pedro. Território de Epidauro... Op. cit., p. 223-246. Capítulo "Um Manuscrito de Medicina Popular do Fim do Século XVIII e Princípios do XIX. II".
} 
Sobre os legumes, plantas comestíveis e frutas da terra, como os ananases, pitombas, pitangas, maracujás, araçás e goiabas. Sobre a preparação de comidas de origem vegetal e típica da cozinha nacional, como os beijus e as farinhas feitas com a mandioca. Sobre o cultivo da cana. Sobre as caças de pena e pata e sobre os animais de ceva como cabritos, borregos, capados, carneiros e bois. Fala do cultivo do tabaco e das ervas medicinais de nossa flora. ${ }^{47}$

As admiráveis Lendas e Canções Populares, do poeta cearense Juvenal Galeno, abundam em informações sobre alimentos como a paçoca e a macaxeira: sobre bebidas como a aguardente e o cauim; sobre a vestimenta e o interior das casas nortistas; sobre a morte e os enterramentos; sobre os pactos com o maligno de que se pode tirar toda sorte de conclusões não só sobre a higiene e a alimentação, como sobre a psicologia profunda e as crenças do brasileiro em geral e a do cearense em particular. ${ }^{48}$

Verificam-se amiúde na obra naviana tópicos como: disponibilidade de recursos, economia, movimentos migratórios, mudança de preferências alimentares, relações interpessoais e muitos outros fatores que determinam influências e ingredientes da mesa brasileira. "A Medicina de Os Lusíadas" (1961) é texto referencial para se perscrutar as conexões entre culinária e medicina que teriam vindo da cultura portuguesa para o Brasil colônia. ${ }^{49} \mathrm{O}$ tema foi exposto por Raimundo Nunes neste excerto:

Durante vinte e sete vezes, Os Lusíadas mencionam a listagem cansativa de ingredientes comestíveis, encontrados nas cidades e portos visitados - viandas, vinho e temperos - numa espécie de operação compensadora daqueles estados de jejum forçado, aceitando de bom grado, qualquer sorte de alimento feito de maneira diferente e reforçado de especiarias desconhecidas. E os navegantes se adaptaram com facilidade, transmitindo novo hábitos alimentares às comunidades patrícias. Resultou daquele intercâmbio culinário, segundo expressões do Nava, "a cozinha mais prodigiosa do mundo", que ele denomina com entusiasmo de "culinária épica e eclética, talássica e telúrica". ${ }^{50}$

Com ampla gama de temas, essas informações se registram, como notou Silva:

Conforme experiências que configuram a multiculturalidade de seu povo - o brasileiro - através de descrições que apresentam, de forma peculiar, aspectos da alimentação, das relações sociais e familiares [...] impregnados no seu eu e no imaginário social brasileiro por ele relatado. ${ }^{51}$

Observem-se, nesta passagem, os costumes alimentares presentes nos ritos funerários do Maranhão oitocentista:

Resplandecente São Luís... Alegre São Luís - em que até os enterros eram motivo de festa. Lavado e amortalhado o corpo, bem posto no seu caixão, saía imediatamente o cortejo para o velório na casa dos amigos. Porque cada um disputava o pobre morto e queria hospedá-lo em câmara-ardente uma ou duas das vinte e quatro horas que ele tinha para entrar de porta em porta, no seu passeio derradeiro. Improvisava-se a essa, recoberta das mais ricas colchas, das mais belas rendas, das mais virentes flores, cercada dos castiçais de prata queimando altas velas, e armava-se a mesa para o festim funerário. Abancavam todos. Comia-se de rijo; águas ardentes e vinhos corriam como o Pindaré e o Itapicuru nas grandes cheias. Depressa minha gente, que ainda temos muita

\footnotetext{
47 NAVA, Pedro. Capítulos da História da Medicina no Brasil. Cotia, SP: Ateliê, 2004, p. 19.

${ }^{48}$ Ibidem, p. 26.

${ }^{49}$ NAVA, Pedro. A Medicina de Os Lusíadas e outros textos. Cotia, SP: Ateliê, 2004.

50 NUNES, Raimundo. Pedro Nava... Op. cit., p. 137.

${ }^{51}$ SILVA, Lenina Lopes Soares. Narrativas do Brasil... Op. cit. , p. 82.
} 
casa para entrar antes da última... E seguia o préstito aumentado em cada esquina pela perspectiva da vinhaça e comezaina. No fim o caixão oscilava incerto em mãos variáveis e o defunto, já passado a segundo plano, era apenas elemento acessório da procissão que seguia - festiva e lúgubre - com arrotos, soluços, ânsias de vômito, imprecações de órfãos, fungações de riso abafado e gritaria de viúva a todo pano. Só na hora do memento e do abismo dos sete palmos, cessava o alarido e todos silenciavam num arrepio - cada qual pensando no dia da Cólera em que seria pretexto de bródio igual. Acredite na história quem quiser. Eu acreditei, quando a ouvi, contada pelo mais veraz dos maranhenses: Antônio Ennes de Souza. Estranha e perturbadora São Luís... ${ }^{52}$

A erudição do autor configura-se no texto em forma de mosaico, na reconstituição do passado pela lembrança de relatos orais ou por meio de bibliografia específica, como a Literatura de viagem: "vou ter inevitavelmente às baías de São Marcos e de São José e com meu companheiro de curso, Roberto Avé-Lallemant, chego a São Luís (que ele chamou de resplandecente e achou parecida com Funchal) naquele ano de $1859 " .53$ A linguagem evocativa da arte simbolista do século XIX, reforça, através da enárgeia, o efeito pictórico da narração que descreve "la douceur qui fascine et le plaisir qui tue" das passantes nas ruas de São Luís: ${ }^{54}$

É nelas que, vindas da missa de São Tiago, de São Pantaleão, da Catedral, passam as mulatas, caboclas, negras e puris descritas pelo viajante - ombros, braços, colo, espáduas completamente nus. [...] Todas elas saborosas como os artocarpos da terra e doces como a compota de bacuri que aperta a garganta e estrangula de tanta doçura. ${ }^{55}$

Robert Avé-Lallemant esteve no Brasil de 1837 a 1855, atuando como médico por treze anos na Santa Casa de Misericórdia do Rio de Janeiro, no lazareto da Ilha do Bom Jesus, no de Nossa Senhora do Livramento, no Conselho de Saúde do Império e no Hospício D. Pedro II. Em 1855, tornou a Lubeck, sua cidade natal. Dois anos depois, foi admitido como médico na expedição de circum-navegação da real e imperial fragata austríaca Novara, da qual se demitiu ao chegar no Rio de Janeiro, a 5 de agosto de 1857. Obteve junto ao Imperador permissão para trabalhar na Santa Casa de Misericórdia. Tendo recebido uma indenização concernente à expedição da fragata Novara, teve permissão para afastar-se por tempo indeterminado do

52 NAVA, Pedro. Baú de Ossos... Op. cit., p. 23.

53 Ibidem, p. 22. Entre os expedicionários que estiveram no Brasil no século XIX, além do explorador alemão Robert Christian Avé-Lallemant, constam em Báu de Ossos os nomes de Jean-Baptiste Debret, James Henderson, Johann Moritz Rugendas, Maria Graham e Thomas Ender. O trecho da obra de Robert Avé-Lallemant citado por Pedro Nava pertence ao segundo tomo de Viagem pelo Norte do Brasil no ano de 1859. É pouco provável que a grafia "Roberto" tenha sido lapso de um escritor minucioso. Aportuguesar o nome Robert seria menos descuido que sugestão da ideia de empatia e identificação com o ponto de vista do médico viajante, evocado como "meu companheiro de curso" pelo autor. Em algumas entrevistas, Pedro Nava definiu sua perspectiva literária e visão de mundo, em grande parte, como resultantes de sua formação médica.

54 "A doçura que envolve e o prazer que assassina". BAUDELAIRE, Charles. Poesia e Prosa. Rio de Janeiro: Nova Aguilar, 1995, p. 179. Tradução da autora.

${ }^{55}$ NAVA, Pedro. Baú de Ossos... Op. cit., p. 22. 
serviço médico e pode dedicar-se ao projeto das viagens pelas províncias do Brasil. A viagem para o Nordeste teve início em novembro de $1858 .{ }^{56}$

As observações de Robert Avé-Lallemant sobre São Luís do Maranhão "naquele ano de 1859 - quando ela era a quarta cidade do Brasil, quando meu avô e Totó Ennes adolesciam", fornecem um referencial histórico ao leitor nas passagens biográficas sobre o maranhense Pedro da Silva Nava e seu "primo, irmão adotivo, compadre e melhor amigo - Antônio Ennes de Souza". A viagem como tema e metáfora literária precede a menção a Robert AvéLallemant: "sou periodicamente atuado pela necessidade de ir a São Luís do Maranhão. Essa sempre e procrastinada viagem, se não a faço com o corpo, realizo em imaginação" e culmina, páginas adiante, na alusão a Marcel Proust: ${ }^{57}$ "a batida no Ceará é uma rapadura diferente. A batida de minha avó Nanoca é para mim coisa à parte e funciona no meu sistema de paladar e evocação talqualmente a madeleine da tante Leonie [...] A batida é viagem no tempo". ${ }^{58}$ São possivelmente estas duas passagens de Robert Avé-Lallemant que Pedro Nava reuniu para comparar as belezas "descritas pelo viajante" aos doces "ortocarpos da terra":

Nas ruas do Maranhão circulava gente endomingada. Uma multidão de mulheres e moças de cor, nas cidades duma mistura de pelo menos três raças [...] O calor do Maranhão, a 2 e 1/2 graus do Equador, justifica a nudez dos ombros, do colo e dos braços até as espáduas, o que faz realçar vantajosamente as formas, muitas vezes realmente belas, dessas mulheres de cor. Mas um pente, como uma torre, que trazem na cabeça, muito enfeitada de flores, é inteiramente sem gosto. Essa inevitável exibição dos adornos na cabeça das mulheres do povo lembram-me dos gorros de bico de gente da Madeira, como aliás, muitos lugares do Maranhão me fizeram lembrar a aprazível Funchal. ${ }^{59}$

Devo lembrar, ao lado de toda essa riqueza, as diversas espécies de anonáceas, de frutos doces como açúcar: o pacuri crescendo até se tornar árvore colossal, a Platonia insignis [...] de frutos comestíveis e muito apreciados, sobretudo, em compota e geleia, exportados e já conhecidos na Europa. ${ }^{60}$

Celina Fontenele Garcia evidenciou a profusão de fontes e referências culturais nas Memórias, conferindo aspecto dual à estrutura narrativa dos planos biográfico e autobiográfico. Na concepção proustiana de memória associativa, o paladar participaria (como gatilho) de um mecanismo sensorial e psicológico de "viagem no tempo", processo mnemônico que evoca a durée bergsoniana. Portanto:

A leitura de Proust confere ao estilo de Nava a fluidez e a descontinuidade do tempo na escritura; a memória involuntária e suas madeleines retiram de sua escritura a característica do documento, de relatório: Baú de ossos, Balão cativo e Chão de ferro constituem, pois, uma mescla do permanente, da fluidez ou

\footnotetext{
56 SIMON, Everton Luiz. Do Garfo à pena: uma história da alimentação do Rio Grande do Sul a partir de relatos de viajantes oitocentistas. 2019. Tese (Doutorado em História) - Universidade do Vale do Rio dos Sinos, São Leopoldo (RS), p. 82-84.

57 NAVA, Pedro. Baú de Ossos... Op. cit., p. 22.

${ }^{58}$ Ibidem, p. 35.

59 AVÉ-LALLEMANT, Robert. Viagem pelo Norte do Brasil no ano de 1859. Vol. 2. Brasília: Instituto Nacional do Livro - Ministério da Educação e Cultura, 1961, p. 21-22.

${ }^{60}$ Ibidem, p. 39.
} 
descontinuidade, uma união da memória documental e da memória involuntária. ${ }^{61}$

Nas Memórias, o tópico da alimentação encontra-se cercado de referências literárias de toda ordem; de "casos" repetidos "sem cessar" por pessoas mais velhas, parentes, agregados e amigos dos Nava; e de conjecturas sobre as mulheres da família paterna, no Ceará, em meados do século XIX: "Deviam encher as noites conversando sobre partos, costuras, riscos de rendas, desenhos de varanda de rede, prenhezes, abortos, receitas de doce, receitas de droga, mezinhas". ${ }^{62}$ Segundo alegou Panichi:

A descrição de assuntos culinários abrange quase todos os sentidos, ou seja, visão, audição, olfato e paladar, revelando um aguçado senso de observação e esmiuçamento da memória, pois envolve passagens que vão da infância à fase adulta. Consegue o autor pelo pitoresco da linguagem, pelo cuidado com a pesquisa e pelo vigor das imagens transferir à culinária a aplicação diligente da vocação da arte literária. ${ }^{63}$

Ilma de Castro Barros e Salgado distinguiu várias imagens de "cidades-literárias" ao analisar a representação do espaço nas Memórias, cujos episódios (auto)biográficos formariam uma espécie de itinerário ou memorial descritivo sobre certas localidades, as quais reportam a etapas importantes da vida do autor e de alguns perfis biográficos. ${ }^{64}$ Atenção especial dedicou Pedro Nava à arte culinária das mulheres da família ${ }^{65}$, superpondo, em dado momento, os conceitos de laboratório e cozinha. Esta última, segundo arguiu Garcia: "lugar de preparo e conservação dos alimentos, onde se temperam e se misturam as várias substâncias dosadas com equilíbrio e saber". ${ }^{66}$ A descrição dessas cozinhas é exuberante e minuciosa, em seus fundamentos materiais (artefatos, ingredientes, plano arquitetônico e registros manuscritos) e imateriais (procedimentos, usos, conhecimentos transmitidos e autênticos).

Segundo Jesús Contreras e Mabel Gracia, os comportamentos socioculturais são poderosos e complexos: categorizações, princípios de exclusão e de associação entre alimentos; prescrições e proibições tradicionais e religiosas; ritos da mesa e da cozinha estruturam a alimentação cotidiana. Os usos dos alimentos, a composição, a ordem e o número de refeições diárias estão codificados de modo preciso. Certo número de "indicadores" gustativos afirma uma identidade alimentar, delimita com vigor a filiação culinária a um território. Assim, o uso de um tipo de gordura para cozinhar marca "fronteiras" culinárias específicas: azeite de oliva no sul do mediterrâneo, banha de porco ou manteiga no oeste, etc.

61 GARCIA, Celina Fontenele. Pedro Nava e a aquisição de sua identidade cultural. Revista do Gelne, Natal, v. 3, n. 1, p. 1-4, 2001.

62 NAVA, Pedro. Baú de Ossos... Op. cit., p. 56.

63 PANICHI, Edina Regina Pugas. As genealogias culinárias de... Op. cit., p. 65.

64 SALGADO, Ilma de Castro Barros e. Cidades literárias: personagens geográficas nas memórias de Pedro Nava. In: SILVA, Francisco Bento da; NASCIMENTO, Luciana Marino do (Orgs.). Cartografias urbanas, olhares, narrativas e representações. Rio de Janeiro: Letra Capital, 2013, p. 239-257.

65 SALGADO, Ilma de Castro Barros e. Pedro Nava: Mulheres reveladas e veladas. Juiz de Fora, RJ: Editar, 1999, p. 81.

${ }^{66}$ GARCIA, Celina Fontenele. A escrita Frankenstein de Pedro Nava. Fortaleza: UFC Ed., 1997, p. 97. 
Histórias nacionais e atitudes individuais relativas à alimentação são entendidas com mais clareza quando ligadas aos costumes alimentares e às particularidades que lhes são próprias. ${ }^{67}$

Há costumes alimentares, afirmou Ellen F. Woortmann, profundamente arraigados na família, a qual "não se reproduz apenas biologicamente, nem reproduz apenas sua força de trabalho. Ela se reproduz também simbolicamente, e uma das dimensões dessa reprodução pode ser apreendida pelo modo de comer". ${ }^{68}$ Famílias engendram culturas de alimentação. Estas culturas se expressam no contexto histórico e socioeconômico tanto como no papel da alimentação como atividade biológica:

Dona Rosa Alexandrina de Barros Palácio. Essa grande senhora deixou nos sobrinhos-netos a lembrança de sua severidade inflexível e no coração de todos, saudade impagável [...] foi a sombra tutelar de meu Pai. [...] Era ela que assistia às refeições de meu Pai, um olho no prato e outro no ponto de crochê ("Coma com modos, Cazuza! Feche as asas e mastigue de boca fechada, menino!") e que, ao fim, dava-lhe com mão irresistível e de boca abaixo, na última garfada, tudo que os luxos infantis tinham separado na boca do prato: fiapos da cebola, casquinhas do alho, películas do tomate, marinheiros do arroz, pevides da pimenta e pelanca das carnes. E o conselho final de raspar o prato, de não deixar restos, de não desperdiçar a comida que a tantos faltava. ${ }^{69}$

D. Rosa Alexandrina era tia materna de D. Ana Cândida (Nanoca). Foi designada para cuidar da moça viúva de 27 anos e seus cinco filhos: Cândida, de sete anos; Dinorá, de seis; Alice, de cinco; José, de quatro e Maria Euquéria, de seis meses. Instalaram-se em Fortaleza, à Rua Senador Pompeu, logo após o sepultamento de Pedro da Silva Nava, no Rio de Janeiro, a $1^{\circ}$ de junho de 1880 . É provável que nesse período de luto, a rotina da casa estivesse nas mãos de D. Rosa Alexandrina: "Uma adulta rigorosa que se [fez] amar de crianças" e influiu na criação de José Nava, "a quem ligou-se a velha tia, pouco a pouco transformada em sua mãe adotiva". Na casa onde viviam três gerações da mesma família, o modo como José era alimentado e devia se portar à mesa expressa uma cultura alimentar:

Enfim, ela "fala" de, ela é uma "expressão" de, ela é a "representação" de algo. Com isso podemos afirmar que a comida 'fala' da família, de homens e de mulheres, tanto para o pesquisador que realiza uma leitura consciente dos hábitos de comer, como para os próprios membros do grupo familiar - e através deste, da sociedade - que realizam uma prática inconsciente de um habitus alimentar [...] destacando que a linguagem expressa através da comida, nem sempre mantém o mesmo significado. ${ }^{70}$

As escolhas alimentares e culinárias de um grupo familiar, a relação dos produtos específicos de cada região, as formas e ocasiões de preparo dos alimentos comentadas por Pedro Nava indicam o aporte histórico e sociológico das Memórias. Esses assuntos serão analisados nas secções seguintes.

\footnotetext{
67 CONTRERAS, Jesús; GRACIA, Mabel. Alimentación y Cultura: Perspectivas antropológicas. Barcelona: Ariel, 2005, p. 12.

68 WOORTMANN, Ellen F. A comida como linguagem. Habitus, Goiânia, v. 11, n. 1, p. 5-17, jan.-jun. 2013, p. 6.

69 NAVA, Pedro. Baú de Ossos... Op. cit., p. 79-80. Grifos no original.

70 WOORTMANN, Ellen F. A comida como linguagem... Op. cit., p. 11.
} 


\section{"As mulheres eram doces"}

Os excertos biográficos sobre o "maranhense Pedro da Silva Nava" e sua mulher, a "cearense D. Ana Cândida Pamplona da Silva Nava", relacionam-se a três locais: "a freguesia de Nossa Senhora da Conceição de São Luís do Maranhão", onde nasceu o avô do autor; Fortaleza, cidade em que se estabeleceu, casou e teve filhos; e o Rio de Janeiro, para onde mudou com a família, em "fins de 1878 ou princípios de 1879", devido à "tremenda desgraça que se abateu sobre a província com a seca de 77 e seu cortejo de horrores". ${ }^{71}$ Em Fortaleza e no Rio de Janeiro, os Nava frequentaram a casa do irmão mais velho de D. Nanoca, o "Comendador Iclirérico Narbal Pamplona, deputado provincial". A família Pamplona "contava várias gerações de antepassados luso-cearenses", o que importa referir ao se conjecturar sobre os hábitos e influências alimentares mantidos no grupo familiar. A opulência da mesa do Comendador Pamplona constitui matéria de interesse para o historiador e o sociólogo.

O escritor sugere a origem de vários pratos. No excerto analisado neste estudo, porém, não se mencionam receitas, mas é possível observar a influência da culinária portuguesa e de ingredientes próprios a uma região na cozinha "da crotálica Dona Irifila [...] fera familiar, esposa proprietária de Iclirérico Narbal Pamplona - político, comendador e mártir doméstico". ${ }^{72}$ Observador da natureza humana, leitor erudito e pesquisador das ciências médicas e sociais, Pedro Nava conciliou inúmeros dados e fontes na reconstituição de perfis biográficos e o de D. Irifila seria um dos mais interessantes.

"Mas que haviam de fazer as senhoras de sobrado, às vezes mais sós e mais isoladas que as iaiás de engenhos? Quase que só lhes permitiam uma iniciativa: inventar comida. 0 mais tinha de ser o rame-rame da vida de mulher patriarcal", ${ }^{73}$ ponderou Freyre em Sobrados e Mucambos (1936), ao se referir a um modelo socioeconômico de cariz escravocrata e rural que, notadamente nas regiões do Nordeste açucareiro, permaneceria até o último decênio do século XIX, de um modo geral, "limitando as oportunidades da mulher ao serviço e às artes domésticas, ao contato com os filhos, a parentela, as amas, as velhas, os escravos". ${ }^{74}$ Exceções houve, porém, registradas, a princípio, na Literatura de viagem e nos textos de cronistas históricos do período colonial. Nesse sentido, é extensa a quantidade de informações que se pode encontrar na cultura popular, literatura, historiografia e no plano biográfico sobre D. Federalina ou Fideralina Augusto Lima (1832-1919), conhecida pela influência política na região do Cariri cearense. ${ }^{75}$ É detalhado o comentário feito por Freyre em relação a: "Quase

\footnotetext{
${ }^{71}$ NAVA, Pedro. Baú de Ossos... Op. cit., p. 62.

72 Ibidem, p. 29.

73 FREYRE, Gilberto. Sobrados e Mucambos. Rio de Janeiro: Record, 1996, p. 36.

74 NAVA, Pedro. Baú de Ossos... Op. cit., p. 29.

${ }^{74}$ FREYRE, Gilberto. Sobrados e Mucambos... Op. cit., p. 93.

${ }^{75} \mathrm{Na}$ cultura popular, cf.: MIRANDA, Ana. Histórias contadas pelo vento. Fortaleza: Dummar, 2019. Na literatura, cf.: HOLANDA, Heloísa Buarque; QUEIROZ, Rachel de. Matriarcas do Ceará: Dona Federalina de Lavras. Rio de Janeiro: CIEC, 1990. Na historiografia e no plano biográfico, cf.: MACEDO, Dimas. Dona Fideralina Augusto: Mito e realidade. Fortaleza: Armazém da Cultura, 2018; MENEZES, Thiago de. Uma vida só não basta. São Paulo: Selo, 2015; PAIVA, Melquíades Pinto. Uma matriarca do sertão: Fideralina
} 
matriarcas que tiveram seus capangas, mandaram dar suas surras, foram 'conservadoras' ou 'liberais' no tempo do Império". ${ }^{76} \mathrm{O}$ jornalista Thiago de Menezes escreveu que D. Fideralina: "De monarquista converteu-se em republicana; o que the interessava era dominar a região de Lavras da Mangabeira. Ela conseguia sempre estar bem com os governos". ${ }^{77} \mathrm{E}$, a memória de Bárbara Pereira de Alencar (1760-1832) não se vincula apenas ao sobrenome de uma família ilustre e aos movimentos pernambucanos de 1817 e 1824, mas igualmente à história da região da vila do Crato, no Ceará: "Do marido de Dona Bárbara conhece-se o nome e quase nada da sua vida, de tal modo o marimacho dominou a cena em sua Família e sua terra", fato salientado biograficamente por Pedro Nava. ${ }^{78}$ Esses exemplos divergem do modelo de mulher brasileira mais comum durante o Império, segundo Freyre:

Muito boa, muito generosa, muito devota, mas só se sentindo feliz entre os parentes, os íntimos, as mucamas, os moleques, os santos de seu oratório; conservando um apego doentio à casa e à família; desinteressando-se dos negócios e dos amigos políticos do marido, mesmo quando convidada a participar de suas conversas. [...] Alheia ao mundo que não fosse o dominado pela casa - a família, a capela, os escravos, os moradores pobres do engenho, os negros dos mucambos mais próximos. Ignorando que houvesse Pátria, Império, Literatura e até Rua, Cidade, Praça. ${ }^{79}$

O crítico literário Antonio Candido destacou uma característica essencial da técnica narrativa de Pedro Nava para relatar o passado. Na escrita (auto)biográfica naviana, a discrepância entre os tempos da ação e da narração busca reparar imaginativamente lacunas não preenchidas de maneira absoluta por fontes orais e documentais, o que pressupõe o estabelecimento imediato de uma situação ficcional. Nesta, tanto o "eu" que experiência o passado como as personalidades biografadas estão sendo recriados fora da memória, usando fontes auxiliares, e no panorama de determinado quadro conceitual pelo "eu" que compõe a narrativa, estruturando de modo criativo e reflexivo a história. ${ }^{80}$

A essa expressiva característica da arte de recordar, alia-se, no âmbito da memória voluntária, a tarefa de manter vivo um arquivo de relatos orais com raízes na tradição local mas, igualmente, no repertório familiar que inclui, "na rede dos parentescos", "a anedota que ficou na nossa família", o "assunto tabu", o "caso", a "legenda cochichada" e "a lembrança dos pequenos fatos". Recuperar tal acervo é meio percuciente para se depurar particularidades físicas e psíquicas de retratos biográficos:

Os irmãos, os cunhados, os sobrinhos ouviam sempre reverentes o respeitável Comendador da Ordem Militar de Nossa Senhora da Conceição de Vila Viçosa e dentro do silêncio propício sua frase alongava-se alta, clara, elegante, oratória,

Augusto Lima. Fortaleza: Livro Técnico, 2008; FARIAS, Airton. História do Ceará. Fortaleza: Armazém da Cultura, $[s . d$.$] ; MACEDO, Joaryvar. Império do bacamarte: uma abordagem sobre o coronelismo no$ Cariri cearense. Fortaleza: UFC; Casa José de Alencar; Programa Culturais, 1990.

${ }^{76}$ FREYRE, Gilberto. Sobrados e Mucambos... Op. cit., p. 95.

77 MENEZES, Thiago de. Uma vida só não... Op. cit., p. 318.

${ }^{78}$ NAVA, Pedro. Baú de Ossos... Op. cit., p. 174-175.

79 FREYRE, Gilberto. Sobrados e Mucambos... Op. cit., p. 112.

80 CANDIDO, Antonio. Poesia e ficção na autobiografia. In: A educação pela noite \& outros ensaios. São Paulo: Ática, 1989, p. 51-69. 
as vogais bem abertas - para só abaixar-se, tornar-se confusa e sumir-se num gaguejado e num sussurro quando a mulher, deixando a roda das cunhadas e da sogra aproximava-se do grupo dos homens. Era hora de irem para casa e Dona Irifila, em vez de simplesmente chamar o marido, gostava de perturbá-lo. [...] Foi assim numa noite em que o Comendador conversava com meu avô, recémcasado na família e seu cunhado de pouco. Justamente o Iclirérico e o Itríclio enfronhavam-no na rede dos parentescos dos avós dos dois e na trama formada pelos Rodrigues, Pamplonas, Barros e Palácios, quando a Irifila veio se chegando em roscas moles que de repente enlaçaram o marido-Laocoonte e estalaram-lhe os ossos com o arrocho da pergunta terrível: "Lequinho, você já explicou a Pedro Nava de que quartel de sua família saiu o tio negreiro?" O Comendador tentou um sorriso que mais parecia a contração de um choro sem lágrimas, engasgou-se no meio da frase, ficou calado e todo trêmulo. ${ }^{81}$

Nesse modelo mnemônico, a valorização do detalhe torna mais nítidos traços de caráter que persistiram ao longo de uma vida, condensa-os e põe em relevo a essência de certa personalidade, facilitando sua longevidade na memória do grupo. Ao descrever a casa, o estilo de vida, os hábitos de alguém, Pedro Nava aclara para o leitor o contexto e as qualidades representativas dos biografados:

Era casada, como já se viu, com o comendador Iclirérico Narbal Pamplona, dos irmãos mais velhos de minha avó paterna, pois nascera no Aracati a 14 de outubro de 1830. Ninguém compreendia o seu casamento. Ele era alto, desempenado, elegante, cheio de calma e distinção. Sua mulher era baixota, atarracada, horrenda, permanentemente irritada - de alma amarga e boca desagradável. [...] Essa Irifila - que tinha títulos para figurar entre as megeras da família de minha avó materna - era uma presença aberrante na de minha avó paterna, onde as mulheres eram doces, laboriosas, submissas, modestas, de lágrima fácil, prontas a calar e de bondade imensa. Diante dessas antonímias, a Irifila abusava. Trazia a sogra, as cunhadas, os cunhados, as filhas, os filhos e os sobrinhos no mesmo cortado em que tinha o marido. Era inimiga de tudo que favorece a fantasia e torna a vida suportável. Era contra os namoros, contra o riso, contra as festas, contra as cantigas, contra as danças, contra o álcool, contra o fumo, contra o jogo. Não gostava de receber e, quando era constrangida a isto, fazia-o com ostentação e grosseria. ${ }^{82}$

Os dados de ordem geográfica, histórica e sociológica que Pedro Nava oferece sobre o casal Pamplona são importantes na observação dos pratos e alimentos incluídos nesse episódio biográfico, registro procedente de pesquisas, entrevistas com familiares e recordações pessoais do memorialista. Essa profusão de fontes é recorrente no método composicional das Memórias, gerando importantes informes sobre uma gama de tradições e formas de representação social relacionadas à alimentação.

\section{"A doçura que envolve e o prazer que assassina"}

A onipresença da gastronomia em alguns episódios de Baú de Ossos relativos à família paterna do memorialista chama atenção para transformações significativas na história do Nordeste brasileiro durante a segunda metade do século XIX, que envolvem o declínio da economia açucareira; a grande seca dos anos setenta; as repercussões culturais, econômicas,

81 NAVA, Pedro. Baú de Ossos... Op. cit., p. 51-52.
82 Ibidem, p. 29. 
políticas e sociais desencadeadas pelo movimento abolicionista; os movimentos migratórios e de urbanização com sentido europeizante:

Não é difícil conjecturar os motivos que trouxeram meus avós para a capital do Império. Primeiro, as viagens à Europa, requintando a mentalidade dos dois e dando-Ihes ambição de vida mais alta em meio maior e mais elegante. Depois a tremenda desgraça que se abateu sobre a província com a seca de 77 e o seu cortejo de horrores. ${ }^{83}$

Já os Pamplona teriam migrado do Ceará para o Rio de Janeiro em razão dos cargos ocupados pelo Comendador no Império. Segundo o Barão de Studart, Iclirérico Narbal Pamplona atuou como deputado provincial pelo Ceará de 1864 a $1865 .^{84}$ O Tribunal da Relação da Corte de 1875 refere que:

Iclirérico Narbal Pamplona, nascido em 14.10.1830, em Aracati, Ceará, e falecido em 29.10.1896, no Rio de Janeiro, na rua do Ipiranga 63 - sepultado no Cemitério do Caju. Filho de Cândido José Pamplona e de Maria de Barros Palácio. Escrivão dos Feitos da Fazenda. Em 1875 residia na Rua de José Bonifácio, número 25, em São Domingos, cidade de Niterói, província do Rio de Janeiro. Em 1885 residia na rua Dona Ana Nery, no 122, cidade do Rio de Janeiro. Em 1889 ainda exercia o cargo de Escrivão de Apelação do Tribunal da Relação da Corte do Rio de Janeiro. Residia na rua Henrique Dias, no 24, em Riachuelo. Deputado à Assembléia Provincial do Ceará. Cavaleiro da Ordem Militar de Nossa Senhora da Conceição de Nova Viçosa de Portugal. Fidalgo da Casa Real, com Brasão de Cota e Armas - eis aqui um caso raro de um Brasão de Armas concedido a um brasileiro, que não consta dos apontamentos que restaram sobre estas concessões, devido ao desaparecimento de alguns dos nossos Livros do Cartório de Nobreza. Esta conceção é anterior ao ano de $1879 .{ }^{85}$

Senhores de engenho e barões do café mantinham propriedades simultaneamente no campo e na cidade, com mesa farta e servidos por grande número de escravos. Funcionários da Casa Imperial, fidalgos e burgueses patriarcais adquiriam novos hábitos, de acordo com suas aspirações de projeção social. Eram preocupações da alta sociedade a etiqueta à mesa, a questão do que comer e beber, o que mais tarde seria assunto para os higienistas do século XX. Em nota ao ensaio do Dr. Luís Pereira Barreto (1840-1923), "A higiene da mesa", publicado na edição de 7 de setembro de 1822 d'O Estado de São Paulo, Luís da Câmara Cascudo comentou o "elogio científico" do médico formado pela Universidade de Bruxelas à cozinha brasileira. ${ }^{86}$ "Regras de servir a mesa", do mesmo autor, constaria em "edição anterior a 1897 (a última do século XIX)" do Cozinheiro nacional, da Livraria Garnier. ${ }^{87}$

Importar hábitos e produtos da Europa era indício de projeção social, refinamento e cultura. "Antes de as vasilhas de louça e de vidro fabricadas na Inglaterra tornarem-se de uso corrente entre a burguesia dos sobrados grandes, comia-se geralmente em louça holandesa e

\footnotetext{
83 NAVA, Pedro. Baú de Ossos... Op. cit., p. 62.

84 STUDART, Guilherme. Dicionário bio-bibliográfico cearense. Vol. I. Fortaleza: Ed. UFC, 1910, p. 380381.

85 BARATA, Carlos Eduardo de Almeida. Tribunal da Relação da Corte - 1875 Subsídios BiográficoGenealógicos. [S. d. t.]. Disponível em: http://www.cbg.org.br/wp-content/uploads/2012/07/tribunal-darelacao-da-corte.pdf. Acesso em: 19 abr. 2020.

${ }^{86}$ BARRETO, Luís Pereira. A higiene da mesa. In: CASCUDO, Luís da Câmara. Antologia da Alimentação no Brasil. São Paulo: Global, 2008, p. 40.

${ }^{87}$ Ibidem, p. 44.
} 
em tigelas portuguesas de boca larga e fundo pequeno [...] [com] a prata fina dos garfos e das colheres", asseverou Freyre. ${ }^{88}$

Nos guarda-louças e aparadores da próspera burguesia dos sobrados constavam, junto da louça "de feitio holandês [...] as travessas da Índia, os pratos fundos de Macau, a porcelana da China. Até arroz-doce se vendia nas ruas em prato de porcelana da China [...] pratos da China ou da Índia cujos azuis e vermelhos brilhavam ao luar" ${ }^{89}$ Cristais e porcelanas finas da Companhia das Índias trazendo brasões ornavam a variedade das preparações culinárias e a inventividade na apresentação dos pratos. "A mesa era patriarcal. O dono da casa, à cabeceira, às vezes servia. Quando era jantar com senhoras, ficavam sempre marido e mulher juntos. Mas isto já foi depois da sofisticação dos hábitos, ao contato maior com a Europa". ${ }^{90} \mathrm{~A}$ mesa deveria refletir a posição privilegiada dos donos da casa na sociedade e D. Irifila adotava a tendência de "ornamentação excessiva da aristocracia": ${ }^{91}$

Na sua casa do Rio de Janeiro (que ficava à Rua Farani em Botafogo), no meio das sedas dos seus reposteiros, dos seus tapetes, dos seus espelhos, dos seus jacarandás, dos seus brocados, das suas porcelanas e dos seus lampiões Carcel - suas palavras batiam duras como calhaus, diretas como tiros, incisivas como machadadas. Mas com isso tudo não gritava e nem se arrebatava. Advertia uma, duas, três vezes e, se não obedecida, passava violentamente à ação. $O$ marido, comendador e abastado, gostava de coisas que ela detestava: conversa de amigos, degustação de bom porto e bons charutos, sua rodinha de jogo. E reunia os parceiros uma vez por semana para o voltarete e para a manilha. Terminadas as partidas, vinham as negras - duas para cada bandeja de prata com o chá, o chocolate, as garrafas do vinho, a frasqueira dos licores, o pinhão de coco, as mães-bentas, os cartuchos, as fofas, as siricaias, os tarecos e tudo quanto é bolo da doçura luso-brasileira. Bolo ilhéu, bolo-da-imperatriz, bolos de raiva, esquecidos, brincadeiras, doce do padre, toucinho do céu. ${ }^{92}$

A imagem das "negras - duas para cada bandeja de prata" possui correlativo em Luz e Sombra (1944), de Maria José Dupré, sobrinha-neta de Francisco Xavier Paes de Barros (18311914), Barão de Tatuí. Carlos de Almeida Prado Bacellar referiu-se à "família Paes de Barros, natural de Itu, [como] grande produtora de açúcar" nos séculos XVIII e XIX ${ }^{93}$ As memórias da autora referem o bom convívio do Barão de Tatuí em família. Recordações familiares sobre o período da escravidão podem ter sido integradas às cenas de Luz e Sombra, inspirada em célebre processo judicial do século XIX: ${ }^{94}$

Os escravos dirigidos pelo mordomo Benedito entraram trazendo doces e refrescos e enquanto todos conversavam pausada e cerimoniosamente [...]. Logo mais papai mandou vir champanha na grande bandeja de prata que pesava dezesseis quilos e vinha carregada por dois escravos. ${ }^{95}$

\footnotetext{
${ }^{88}$ FREYRE, Gilberto. Sobrados e Mucambos... Op. cit., p. 217.

${ }^{89}$ Idem.

90 Idem.

91 Ibidem, p. 143.

92 NAVA, Pedro. Baú de Ossos... Op. cit., p. 29-30.

93 BACELLAR, Carlos de Almeida Prado. Viver e sobreviver em uma vila colonial: Sorocaba, séculos XVIII e XIX. São Paulo: Annablume; FAPESP, 2001, p. 108.

94 DUPRÉ, Maria José. Os caminhos. São Paulo: Ática, 1978, p. 106.

95 DUPRÉ, Maria José. Luz e sombra. São Paulo: Brasiliense, 1944, p. 22.
} 
Em O Ceará (Lado cômico). Algumas crônicas e episódios (1899), o historiador João Brígido dos Santos descreveu hábitos alimentares característicos do Ceará rural nos séculos XVIII e XIX: "Um almoço de rico, nos sertões, era antes das 7 horas da manhã, o jantar às 12, a ceia ao cair da noite". ${ }^{96}$ A ceia consistia, quase sempre, em carne com pirão, "um assado com molho chamado 'de ferrugem'" e, por último, uma tigela de caldo. À sobremesa compareciam o melaço com farinha, os "doces de frutas da terra em mel de rapadura", queijo com rapadura, frutas como melancia e melão:

\begin{abstract}
Em mesas de pernas grossas, como de elefante, sobre toalhas de linho, em louça do Porto, deitavam-se carnes e gorduras, doces, queijos e mil coisas da terra, e tudo se comia atribuladamente, de colher, ou fazendo da faca uma colher. Negros e negras retintas serviam à mesa, de toalha ao ombro, com roupas de algodão e os pés descalços, pois que era malcriação - negro andar de chinelas. Os talheres, os copos e as bandejas eram de prata fina, obtida do Porto ou da Bahia, e já havia alguns serviços de porcelana dourada, procedente da Índia. O luxo do tempo era caro, mas era sólido. ${ }^{97}$
\end{abstract}

A ceia na casa dos Pamplonas, durante as "rodinhas de jogo" do Comendador, era feita com "ostentação", oferecendo "bom porto", chá, chocolate, vinho, licores, no entanto, curiosamente, nessa relação não se inclui o café, embora o memorialista refira a presença do "café ritual" à mesa dos avós, em Fortaleza. Segundo João Brígido, até a segunda metade do século XIX, "nos refeitórios do sertão" apesar dos "bons petiscos", feitos por mãos de hábeis quituteiras: "O que não havia, então, era o café, tampouco o chá". ${ }^{98}$ As bebidas oferecidas à ceia por D. Irifila, "na sua casa do Rio de Janeiro", seriam condizentes com hábitos depurados na Capital do império, no convívio com o público, nos termos do historiador, "mais avisado em etiquetas e cerimônias". A influência da culinária portuguesa proviria "de antepassados lusocearenses", mesclada às adaptações, às vogas do tempo e do local.

A "doçura luso-brasileira" mencionada por Pedro Nava é tema recorrente na obra de Afrânio Peixoto. O memorialista associou a figura do escritor à juventude do pai, "o médico cearense Dr. José Pedro da Silva Nava", aluno da Faculdade de Medicina da Bahia, que "ele ainda conheceu intacta, antes do incêndio de 1905, no lugar histórico do velho Colégio dos Jesuítas e frequentou-a no mesmo ano de 1896 em que outro moço de 20 anos, Júlio Afrânio Peixoto, cursava sua quinta série". ${ }^{99}$ Sobre a doçaria conventual, Afrânio Peixoto é citado por Freyre ao comentar os "velhos nomes de quitutes e gulodices" da culinária portuguesa: "sentese às vezes a intenção afrodisíaca, o toque fescenino a confundir-se com o místico: suspiros de freira, toucinho do céu, barriga de freira, manjar do céu, papos de anjo" - nomes evocativos da religiosidade, dos costumes e do imaginário popular: ${ }^{100}$

Lá, como aqui, os doces eram conventuais, por várias causas, que não é ingrato lembrar. Primeiro, convento de freiras, mulheres a quem os doces são

\footnotetext{
${ }^{96}$ BRÍGIDO, João. Outrora, no Ceará... Op. cit., p. 165.

97 Ibidem, p. 167.

98 Ibidem, p. 165.

99 NAVA, Pedro. Baú de Ossos... Op. cit., p. 100.

100 FREYRE, Gilberto. Casa-Grande \& Senzala. Rio de Janeiro: José Olympio, 1964, p. 347.
} 
familiares. [...] Por isso, a piedade intervém, no nome das iguarias: mãe-benta, sopa de frade, biscoitos do bispo, palha de abade (ou fios de ovos), barriga de freira, fatias celestes, bolo da trindade, hóstias, papos de anjo, mistérios, toucinho do céu... e vai por aí. Por vezes profanos e maliciosos, desmamadas, casadinhos (duas bolachinhas com geleia de permeio) apressados, fatias de parida, bons-bocados, levanta-velho, delícias, melindres, mexericos, lamúrias... Não faltam indiferentes, bem gostosos: pão-de-ló (não "de Lot", a personagem bíblica, porém de ló, ou filó, tecido fino e fofo), flor de polvilho, leite-frito, bolo de comadre, espumas de prata, bolinhos bordados, bolo de São João, bolo de aipim, doce de Jeremias... Além dos sem nome... de farinha, de goma, de polvilho, de araruta, de aipim, de carimã, de milho, de fubá, de amêndoas, de arroz, de tapioca, de queijo, de batata, de pão, de pão, de cará, de chocolate, de leite, de ovos, etc. Na rubrica dos nomes singulares não esquecerei: as brevidades, as broinhas, as cavacas, as empoladas, as trouxas, as tigelinhas, os chuviscos, os tarecos, as amodas, os fartes, os palitos, as roscas, os confeitos, os manuscritos, os queimados (no Rio, balas; em Lisboa, rebuçados), os pudins, as pamonhas, as panquecas, as petas, os manjares, as mentiras, as cocadas. Tenho minhas predileções: os beijus de leite, os cuscus, os manuês, (manuê sem manteiga...que bom!), a sericaia, a canjica, o mucumzá, o arroz de leite, ou arroz-doce. ${ }^{101}$

Referindo-se a compilações de receitas que chegaram até o século atual, a historiadora Isabel Drummond Braga declarou que investigar a alimentação nos monastérios e conventos de Portugal na "Época Moderna é uma tarefa difícil que, por vezes, precisa considerar dados indiretos, pois são escassos os manuscritos e, na época, não foram publicadas as receitas, as quais eram entendidas como segredos que circulavam muitas vezes apenas oralmente". ${ }^{102}$ Em Chão de Ferro (1976), Pedro Nava refere um caso que Ihe contou Afonso Pena Júnior, então Secretário do Interior do estado de Minas Gerais, em agosto de 1921. Em feitio de anedota, a passagem poderia ilustrar a reflexão de Braga:

Mostrou-se conhecedor do folclore de minha gente. Parece que foi com parenta sua, morrendo, uma que não ensinava receita de seus quindins a ninguém, nem dos seus bolos e pudins que aconteceu aquele caso. Ria agora de gosto, contando. As velhas vizinhas chegando fofas mandando dizer Jesus! irmã, e fazendo perguntas. Dona Florência, quantas colheres de açúcar? no seu quindim. Duas e meia - arquejava a alma sem defesa. Diz Jesus! irmã, e no seu bolo Santa Cecília mistura a calda com o leite de coco ou o leite de coco com a calda. Mistura sim mas, depois de frio e aí é que se torna a esquentar. Passou macete por macete. ${ }^{103}$

Entre os quitutes citados por Pedro Nava, "o pinhão de coco, as mães-bentas, os cartuchos, as fofas, as siricaias, os tarecos e tudo quanto é bolo da doçura luso-brasileira. Bolo ilhéu, bolo-da-imperatriz, bolos de raiva, esquecidos, brincadeiras, doce do padre, toucinho do

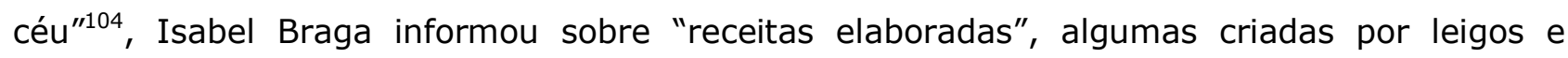
partilhadas por casas conventuais, a exemplo "dos bolos de raiva do Rato, ou seja, do Mosteiro de Nossa Senhora dos Remédios da Santíssima Trindade, de Lisboa" e dos "bolos de raiva do mosteiro de Sacramento, eventualmente o mosteiro masculino do Santíssimo Sacramento, da

\footnotetext{
${ }^{101}$ PEIXOTO, Afrânio. Livro de Horas. Rio de Janeiro: Agir, 1947, p. 281-282.

102 BRAGA, Isabel Drummond. A mesa conventual e os sabores da América. In: RIBEIRO, Cilene Gomes; SOARES, Carmen. Odisseia de sabores da Lusofonia. Coimbra: Imprensa da Universidade de Coimbra, 2015, p. 170.

103 NAVA, Pedro. Chão de Ferro. Rio de Janeiro: José Olympio, 1976, p. 345-346.

104 NAVA, Pedro. Baú de Ossos... Op. cit., p. 30.
} 
ordem dos Eremitas de São Paulo". ${ }^{105}$ Em Arte nova, e curiosa, para conserveiros, confeiteiros, e copeiros, e mais pessoas que se occupaõ em fazer doçes, e conservas com frutas de varias qualidades, e outras muitas receitas particulares que pertencem á mesma Arte (1788), publicado em Lisboa, consta uma "Receita de bolos de raiva" que leva amêndoas, açúcar, manteiga, gemas de ovos, "duas ou três claras" e água de flor. ${ }^{106}$

Em Migalhas folclóricas (1951), Mariza Lira expôs a origem da mãe-benta no Rio de Janeiro do período regencial. A iguaria fez-se tão popular que acabou sendo glosada "num lundu da época". ${ }^{107} \mathrm{Em}$ nota ao texto de Lira, Câmara Cascudo recordou o que expusera anteriormente sobre o doce, no II tomo da História da Alimentação no Brasil. Segundo Câmara Cascudo, a receita da mãe-benta:

está, há século, em Portugal. Lá empregam o fubá de arroz como na receita que Mariza Lira divulgou. Não é a primitiva. Nos "Bolos da Mãe-Benta" do Doceiro Nacional, 7a ed., anterior a 1897, ainda consta farinha de trigo, também alteração. A verdadeira receita trazia a goma de mandioca, polvilho de goma, tradicionalíssimo. Depois é que a farinha de trigo e o fubá de arroz apareceram. O regente Diogo Antônio Feijó saboreou os antigos, com a goma de mandioca, made in Brasil. ${ }^{108}$

$\mathrm{Na}$ relação de doces feita por Pedro Nava ao descrever os serões em casa dos Pamplona, no Rio de Janeiro, as "mães-bentas" teriam certamente mais de um modo de preparo, aqueles vindos do receituário familiar e as formas elaboradas segundo o costume local. O mesmo raciocínio aplicar-se-ia aos cartuchos. Em Açúcar (1939), Freyre descreveu os "cartuchos franjados, de rua - como os de farinha de castanha, por algum tempo popularíssimos, no Recife". 109 "Eram enfeites de papel em forma de franja que tornavam outrora particularmente atraentes aos olhos dos meninos do Recife os cartuchos de farinha de castanha". ${ }^{110}$ Os cartuchos associam-se a tradições religiosas que o sociólogo interpretou como herança ou "expressão lírica de religiosidade" do cristianismo português:

Nas festas de pátio de igreja do Nordeste do Brasil e de outras regiões do país minhas conhecidas, o que se encontra de mais aproximado desse costume de populações portuguesas da Europa e dos Açores são os rosários de castanha-decaju [...]. Conservou-se no Brasil colonial a tradição de acompanharem as procissões pessoas conduzindo tabuleiros ou caixas de doces, que iam oferecendo generosamente, se não a penitentes que se flagelavam - como em Portugal - a indivíduos que representavam figuras da Paixão ou da História Sagrada. ${ }^{111}$

\footnotetext{
105 BRAGA, Isabel Drummond. Sabores \& segredos: receituários conventuais portugueses da época moderna. São Paulo: Annablume, 2015, p. 17, 71.

106 Arte Nova, e curiosa, para conserveiros, confeiteiros, e copeiros, e mais pessoas que se occupaõ em fazer doçes, e conservas com frutas de varias qualidades, e outras muitas receitas particulares que pertencem á mesma Arte. Lisboa: Oficina de José de Aquino Bulhoens, 1788, p. 107.

107 LIRA, Mariza. Nove sopas. Barreado. A origem da Mãe-Benta. In: CASCUDO, Luís da Câmara. Antologia da Alimentação no Brasil. São Paulo: Global, 2008, p. 103.

108 CASCUDO, Luís da Câmara. Antologia da Alimentação no Brasil. São Paulo: Global, 2008 , p. 103. Grifos no original.

${ }^{109}$ FREYRE, Gilberto. Açúcar... Op. cit., p. 39.

110 Ibidem, p. 88.

${ }^{111}$ Ibidem, p. 87.
} 
Os cartuchos eram especialmente consumidos em festas de santos. Em Minha vida de menina (1942), Alice Dayrell Caldeira Brandt (Helena Morley) recordou episódio ocorrido na festa de Nossa Senhora das Mercês, no final do século XIX, em Diamantina, onde se distribuíam cartuchos recheados de amêndoas (ingrediente talvez escasso no lugar) ou com "manuscritos" - "confeitos de cacau":

Veio-me à lembrança um caso de quando eu tinha uns sete anos; e apesar do esforço de vovó, eu sofri uma grande decepção. [...] Na véspera de uma procissão das Mercês, vovó chamou a costureira e encomendou um vestido branco para mim. Nunca poderei esquecer a ânsia com que esperei o dia da procissão, em que eu iria entrar na ala com as primas e ganhar como elas um cartucho de papel de seda repinicado, cheio de manuscritos. [...] Quando a procissão passou eu entrei na ala, justamente na hora em que Seu Broa repartia os cartuchos. Parece que os cartuchos daquele tempo eram maiores que os de hoje, uns cheios de manuscritos e outros de amêndoas. Os de amêndoas eram para os padres, cantores e algumas pessoas mais importantes. Valiam mais do que três dos outros e eu me lembro da inveja que tinha dos que ganhavam deles. Mas o demônio do Broa passou e seguiu sem me dar o cartucho. ${ }^{112}$

XVI:

De origem remota na cultura portuguesa é também a siricaia, com raízes no século

A siricaia [...] não é brasileira e sim portuguesa. Pelo menos veio de lá. [...] A cozinha do mundo português salvou a receita do doce cinco vezes secular: "Siricaia de Goa - Leite, 2 1/2 decilitros. Gemas de ovo, 6. Baunilha, uma colher de chá. Limão, 1. Açúcar, q. b. Ferve-se o leite até engrossar e tira-se do lume. Depois de frio misturam-se-lhe gemas de ovo bem batidas, açúcar, baunilha e casca de limão. Estando tudo isto bem ligado, vaza-se em tigelas e coze-se no forno com fogo brando por cima e por baixo"..$^{113}$

A receita que o folclorista Mário Souto Maior transcreveu em Comes e Bebes do Nordeste (1984), foi registrada antes pelo historiador Mozart Soriano Aderaldo e contém menos ingredientes, se comparada à versão da Bahia, ditada por Hildegardes Vianna e preparada com: 12 gemas; duas rapaduras meladas ou 12 colheres de açúcar grosso; uma colher de manteiga; uma xícara de leite de vaca ou de coco; baunilha - versão julgada por Câmara Cascudo "mais simples, próxima ao modelo do Rio Grande do Sul". ${ }^{114}$ No Brasil, varia a forma de adoçar, com rapadura e outros tipos de açúcar:

Siricaia - "Adocem uma porção de leite de vaca com açúcar branco em pó e nêle se baterão alguns ovos, depois ajuntem-Ihe bastante canela em pó, misture-se tudo e deite-se em xícara de asa ou em canequinhas e vai tudo a cozer no forno, a fogo moderado; estando meio cozida a massa, retira-se, polvilha-se com canela e volta tudo ao forno para acabar de cozer. Serve-se quente nas mesmas vasilhas", receita que Mozart Soriano Aderaldo recolheu no Ceará. ${ }^{115}$

Ao folclore e culinária do Nordeste Câmara Cascudo associou o tareco: "Bolinho torrado, feito de farinha de trigo, ovos e açúcar, redondinhos e saborosos. Indústria pernambucana que

\footnotetext{
112 MORLEY, Helena. Minha vida de menina. São Paulo: José Olympio, 1973, p. 237-239.

113 CASCUDO, Luís da Câmara. Antologia da Alimentação no Brasil. São Paulo: Global, 2008, p. 152-153. Verbete "Siricaia, doce da Índia".

${ }^{114}$ Ibidem, p. 151.

115 MAIOR, Mário Souto. Comes e bebes do Nordeste. Recife: Fundação Joaquim Nabuco; Massangana, 1985, p. 127.
} 
se popularizou pelos estados vizinhos, o tareco é oferecido aos passageiros dos comboios que demandam o Recife, e conhecido por todas as idades". ${ }^{116}$ Mário Souto Maior registrou a receita de Dona Cacilda Menezes, do Recife: "Três ovos, açúcar e farinha de trigo com o mesmo peso dos ovos. Bata as claras, junte o açúcar e as gemas e, por último, a farinha peneirada. Unte uma assadeira e pingue a massa com uma colher de chá. Leve ao forno quente e depois à estufa, para torrar". ${ }^{117}$ Muitos são os produtos de origem europeia e nacional citados por Pedro Nava, mas a "abundância dos doces e dos sequilhos" remete à variedade de pratos feitos a partir do polvilho, elemento usual na culinária do Nordeste. No excerto a seguir, o memorialista relata como D. Irifila pôs término às partidas de jogo do Comendador:

\begin{abstract}
À hora da ceia, requintou-se. Nunca suas bandejas, seus bules e seus açucareiros de prata tinham tido tal polimento. Nunca tirara tanta toalha de renda das arcas e das cômodas perfumadas a capim-cheiroso. Nunca seus guardanapos de linho tinham recebido tanta goma. E que fartura. Chá, chocolate, moscatéis, madeiras, portos. Os licores de França, da Hungria e os nacionais de piqui, tamarindo e jenipapo. E a abundância dos doces e dos sequilhos: língua-de-moça, marquinhas, veranistas, patinhas, creme virgem e tudo quanto é biscoito. Biscoitos a Cosme, espremidos, de queijo, de nata, de fubá, de polvilho, de araruta. E no meio da maior bandeja, a mais alta compoteira com o doce do dia - aparecendo todo escuro e lustroso, através das facetas do cristal grosso, de um pardo saboroso como o da banana mole, da pasta de caju, do colchão de passas com ameixas pretas, do cascão de goiaba com rapadura. O comendador resplandecente destampou a compoteira: estava cheia, até as bordas, de merda viva! [...] Nunca mais sua casa recebeu ninguém até o dia 29 de outubro de 1896 - data em que suas portas se abriram para os amigos que the vinham velar o corpo, enquanto lá dentro, cercadas das filhas e dos parentes, a Irifila uivava à morte... ${ }^{118}$
\end{abstract}

Silva ratificou um aspecto das Memórias que poderia ser estendido ao tópico da alimentação: "A infância lembrada traz ainda aspectos ligados ao vestuário, aos tipos de leitura, às doenças que o acometiam, à alimentação, às brincadeiras infantis em casa e na rua [...] um verdadeiro retrato da infância brasileira como uma narrativa cultural do início do Século $X X^{\prime \prime}{ }^{119} \mathrm{O}$ retrato da alimentação dos Pamplona, enumera elementos inerentes à cozinha de "sua casa no Rio de Janeiro", em Botafogo: "suas porcelanas", "as garrafas do vinho, a frasqueira dos licores", "suas bandejas, seus bules e seus açucareiros de prata", suas toalhas de renda, "seus guardanapos de linho", "a mais alta compoteira com o doce do dia". Conforme observou Silva: "Nesses registros consubstanciam-se narrativas das relações familiares, das práticas alimentares, das festividades e das práticas de sociabilidades [...] disseminadas em obras de autores brasileiros, dentre os quais destacamos: Gilberto Freyre [...] em seu Casa Grande \& Senzala". ${ }^{120}$ No episódio que descreve o fim os serões na casa do casal Pamplona, Pedro Nava traçou um breve histórico da cozinha de uma família burguesa em fins do século XIX.

${ }^{116}$ CASCUDO, Luís da Câmara. Dicionário do folclore brasileiro. Rio de Janeiro: Ediouro, [s. d.], p. 857.

117 MAIOR, Mário Souto. Comes e bebes... Op. cit., p. 126.

118 NAVA, Pedro. Baú de Ossos... Op. cit., p. 30.

119 SILVA, Lenina Lopes Soares. Narrativas do Brasil... Op. cit., p. 101.

${ }^{120}$ Ibidem, p. 204. 


\section{Considerações finais}

Os prazeres da mesa ocupam lugar destacado na passagem sobre o casal Pamplona. 0 requinte barroco do banquete descrito exacerba o impacto do grotesco escândalo alimentar em que o episódio biográfico culmina. Os elementos propriamente ditos da culinária regional - os frutos da terra: coco, piqui, tamarindo e jenipapo, o milho e a mandioca, dos quais derivam o fubá, o polvilho e a araruta, surgem mesclados à produtos importados e à doçaria inspirada na cozinha conventual portuguesa: ${ }^{121}$

com o chá, o chocolate, as garrafas do vinho, a frasqueira dos licores, o pinhão de coco, as mães-bentas, os cartuchos, as fofas, as siricaias, os tarecos e tudo quanto é bolo da doçura luso-brasileira. Bolo ilhéu, bolo-da-imperatriz, bolos de raiva, esquecidos, brincadeiras, doce do padre, toucinho do céu. [...] Chá, chocolate, moscatéis, madeiras, portos. Os licores de França, da Hungria e os nacionais de piqui, tamarindo e jenipapo. E a abundância dos doces e dos sequilhos: língua-de-moça, marquinhas, veranistas, patinhas, creme virgem e tudo quanto é biscoito. Biscoitos a Cosme, espremidos, de queijo, de nata, de fubá, de polvilho, de araruta. ${ }^{122}$

A relação desses artigos, a maior parte documentada por folcloristas e sociólogos, corrobora o traço de excentricidade que se verifica no perfil psicológico de Dona Irifila Rosa Pamplona. O autor realça o aspecto descritivo da passagem com estilo evocativo da anedota histórica, recordando ainda o sentido de observação dos costumes da literatura de viagem. As recordações pessoais de parentes e do próprio memorialista, corroboradas por fontes bibliográficas específicas, além de indicar tópicos relevantes de pesquisa, aproximam a culinária do Nordeste, com suas peculiaridades e influências, de expressões artísticas que despertam os sentidos, como a escultura, a literatura e a pintura.

121 O piqui (Caryocar coriaceum) é um fruto pertencente à família Caryocaraceae, similar ao pequi (Caryocar brasiliense). O primeiro é encontrado nos estados do Maranhão e Piauí (Região Meio-Norte do Brasil), usado comumente em pratos típicos da culinária do Nordeste; o segundo, é característico da culinária da Região Centro-Oeste e oeste de Minas Gerais.

122 NAVA, Pedro. Baú de Ossos... Op. cit., p. 29-30. 


\section{Referências}

ALGRANTI, Leila Mezan. Doces de ovos, doces de freiras: a doçaria dos conventos portugueses no livro de receitas da Irmã Maria Leocádia do Monte do Carmo (1729). Cadernos Pagu, Campinas (SP), n. 17-18, p. 397-408, 2001-2002.

Arte Nova, e curiosa, para conserveiros, confeiteiros, e copeiros, e mais pessoas que se occupaõ em fazer doçes, e conservas com frutas de varias qualidades, e outras muitas receitas particulares que pertencem á mesma Arte. Lisboa: Oficina de José de Aquino Bulhoens, 1788.

AVÉ-LALLEMANT, Robert. Viagem pelo Norte do Brasil no ano de 1859. Vol. 2. Brasília: Instituto Nacional do Livro - Ministério da Educação e Cultura, 1961.

BACELLAR, Carlos de Almeida Prado. Viver e sobreviver em uma vila colonial: Sorocaba, séculos XVIII e XIX. São Paulo: Annablume; FAPESP, 2001.

BARATA, Carlos Eduardo de Almeida. Tribunal da Relação da Corte - 1875 Subsídios Biográfico-Genealógicos. [S. $\quad d . \quad t]$. Disponível em: http://www.cbg.org.br/wpcontent/uploads/2012/07/tribunal-da-relacao-da-corte.pdf. Acesso em: 19 abr. 2020.

BARRETO, Luís Pereira. A higiene da mesa. In: CASCUDO, Luís da Câmara. Antologia da Alimentação no Brasil. São Paulo: Global, 2008.

BRAGA, Isabel Drummond. A mesa conventual e os sabores da América. In: RIBEIRO, Cilene Gomes; SOARES, Carmen. Odisseia de sabores da Lusofonia. Coimbra: Imprensa da Universidade de Coimbra, 2015.

BRAGA, Isabel Drummond. Sabores \& segredos: receituários conventuais portugueses da época moderna. São Paulo: Annablume, 2015.

BRÍGIDO, João. Outrora, no Ceará. In: CASCUDO, Luís da Câmara. Antologia da Alimentação no Brasil. São Paulo: Global, 2008.

CANÇADO, José Maria. Memórias videntes do Brasil: a obra de Pedro Nava. Belo Horizonte: Ed. UFMG, 2003.

CANDIDO, Antonio. Poesia e ficção na autobiografia. In: A educação pela noite \& outros ensaios. São Paulo: Ática, 1989.

CARVALHO, Ana Judith de. Cozinha típica brasileira: sertaneja e regional. Rio de Janeiro: Ediouro, 1998.

CASCUDO, Luís da Câmara. Antologia da Alimentação no Brasil. São Paulo: Global, 2008.

CASCUDO, Luís da Câmara. Dicionário do folclore brasileiro. Rio de Janeiro: Ediouro, [s. d.].

CASCUDO, Luís da Câmara. Doces de tabuleiro. In: Antologia da Alimentação no Brasil. São Paulo: Global, 2008.

CASCUDO, Luís da Câmara. Viajando o Sertão. Natal: Fundação José Augusto; CERN, 1984.

CASCUDO, Luís da Câmara. Superstição no Brasil. São Paulo: Global, 2002.

CASTRO, Josué. Geografia da fome. Rio de Janeiro: Casa do estudante do Brasil, 1953.

CONTRERAS, Jesús; GRACIA, Mabel. Alimentación y Cultura: Perspectivas antropológicas. Barcelona: Ariel, 2005. 
DUPRÉ, Maria José. Luz e sombra. São Paulo: Brasiliense, 1944.

DUPRÉ, Maria José. Os caminhos. São Paulo: Ática, 1978.

FARIAS, Airton. História do Ceará. Fortaleza: Armazém da Cultura, [s. d.].

FREYRE, Gilberto. Açúcar: Uma sociologia do doce, com receitas de bolos e doces do Nordeste do Brasil. São Paulo: Global, 2012.

FREYRE, Gilberto. Casa-Grande \& Senzala. Rio de Janeiro: José Olympio, 1964.

FREYRE, Gilberto. Sobrados e Mucambos. Rio de Janeiro: Record, 1996.

GALENO, Alberto Santiago. Território dos Coronéis. Fortaleza: Henriqueta Galeno, 1988.

GARCIA, Celina Fontenele. A escrita Frankenstein de Pedro Nava. Fortaleza: UFC Ed., 1997.

GARCIA, Celina Fontenele. Pedro Nava e a aquisição de sua identidade cultural. Revista do Gelne, Natal, v. 3, n. 1, p. 1-4, 2001.

HOLANDA, Heloísa Buarque; QUEIROZ, Rachel de. Matriarcas do Ceará: Dona Federalina de Lavras. Rio de Janeiro: CIEC, 1990.

KEARNEY, Richard. On Stories. London; New York: Routledge, 2002.

LIRA, Mariza. Nove sopas. Barreado. A origem da Mãe-Benta. In: CASCUDO, Luís da Câmara. Antologia da Alimentação no Brasil. São Paulo: Global, 2008.

MACEDO, Dimas. Dona Fideralina Augusto: Mito e realidade. Fortaleza: Armazém da Cultura, 2018.

MACEDO, Joaryvar. Império do bacamarte: uma abordagem sobre o coronelismo no Cariri cearense. Fortaleza: UFC; Casa José de Alencar; Programa Culturais, 1990.

MAIOR, Mário Souto. Comes e bebes do Nordeste. Recife: Fundação Joaquim Nabuco; Massangana, 1985.

MELO, Manoel Rodrigues de. Patriarcas e carreiros: influência do coronel e do carro de boi na sociedade rural do Nordeste. Natal: Ed. Universitária, 1985.

MENEZES, Thiago de. Uma vida só não basta. São Paulo: Selo, 2015.

MIRANDA, Ana. Histórias contadas pelo vento. Fortaleza: Dummar, 2019.

MORLEY, Helena. Minha vida de menina. São Paulo: José Olympio, 1973.

NAVA, Pedro. A Medicina de Os Lusíadas e outros textos. Cotia, SP: Ateliê, 2004.

NAVA, Pedro. Baú de Ossos. Rio de Janeiro: José Olympio, 1974.

NAVA, Pedro. Capítulos da História da Medicina no Brasil. Cotia, SP: Ateliê, 2004.

NAVA, Pedro. Chão de Ferro. Rio de Janeiro: José Olympio, 1976.

NAVA, Pedro. Território de Epidauro: Crônicas e Histórias da História da Medicina. São Paulo: Ateliê, 2003.

NOGUEIRA, João. Hábitos e costumes cearenses. In: GIRÂO, Raimundo. O Ceará. Fortaleza: Ed. Fortaleza, 1945.

NUNES, Raimundo. Pedro Nava: Memória. São Paulo: Ateniense, 1987.

PAIVA, Melquíades Pinto. Uma matriarca do sertão: Fideralina Augusto Lima. Fortaleza: Livro Técnico, 2008. 
PANICHI, Edina Regina Pugas. As genealogias culinárias de Pedro Nava. Manuscrítica: revista de crítica genética, São Paulo, n. 35, p. 65-77, 2018.

PANICHI, Edina Regina Pugas. Processos de construção de formas na criação: o projeto poético de Pedro Nava. Londrina, PR: Eduel, 2016.

PAULO, Fernando José de São. Linguagem Médica Popular no Brasil. Vol. 2. Salvador: Itapuã, 1970.

PEIXOTO, Afrânio. Livro de Horas. Rio de Janeiro: Agir, 1947.

POYARES, Pedro de. Tractado panegyrico em louvor da Villa de Barcellos por rezam do apparecimento de cruzes que nela aparecem. Coimbra: Officina de Joseph Ferre, 1672.

SALGADO, IIma de Castro Barros e. Cidades literárias: personagens geográficas nas memórias de Pedro Nava. In: SILVA, Francisco Bento da; NASCIMENTO, Luciana Marino do (Orgs.). Cartografias urbanas, olhares, narrativas e representações. Rio de Janeiro: Letra Capital, 2013.

SALGADO, Ilma de Castro Barros e. Pedro Nava: Mulheres reveladas e veladas. Juiz de Fora, MG: Editar, 1999.

SERVENTI, Silvano; SABBAN, Françoise. Pasta: The Story of a Universal Food. New York: Columbia University Press, 2002.

SILVA, Lenina Lopes Soares. Narrativas do Brasil nas Memórias de Pedro Nava. 2010. Tese (Doutorado em Ciências Sociais) - Universidade Federal do Rio Grande do Norte, Natal.

SIMON, Everton Luiz. Do Garfo à pena: uma história da alimentação do Rio Grande do Sul a partir de relatos de viajantes oitocentistas. 2019. Tese (Doutorado em História) Universidade do Vale do Rio dos Sinos, São Leopoldo (RS).

SOLER, Luís. Origens árabes no folclore do sertão brasileiro. Florianópolis: Ed. UFSC, 1995.

STUDART, Guilherme. Dicionário bio-bibliográfico cearense. Vol. I. Fortaleza: Ed. UFC, 1910.

VIEIRA, António. Sermão da Primeira Dominga da Quaresma. In: Obras Completas do Padre António Vieira. Sermões. Vol. I. Porto: Lello \& Irmão, 1999.

WOORTMANN, Ellen F. A comida como linguagem. Habitus, Goiânia, v. 11, n. 1, p. 5-17, jan.jun. 2013.

ZUSSMAN, Robert. Autobiographical occasions: introduction to the special issue. Qualitative sociology, v. 23, n. 1, p. 5-8, 2000. 